\title{
Impact of land convection on troposphere-stratosphere exchange in the tropics
}

\author{
P. Ricaud ${ }^{1}$, B. Barret ${ }^{1}$, J.-L. Attié ${ }^{1}$, E. Motte ${ }^{1}$, E. Le Flochmoën ${ }^{1}$, H. Teyssèdre ${ }^{2}$, V.-H. Peuch ${ }^{2}$, N. Livesey ${ }^{3}$, \\ A. Lambert ${ }^{3}$, and J.-P. Pommereau ${ }^{4}$ \\ ${ }^{1}$ Université de Toulouse, Laboratoire d'Aérologie, CNRS UMR 5560, Toulouse, France \\ ${ }^{2}$ Centre National de Recherche Météorologique, Météo-France, Toulouse, France \\ ${ }^{3}$ NASA Jet Propulsion Laboratory, Pasadena, California, USA \\ ${ }^{4}$ CNRS, Service d'Aéronomie, Verrières-le-Buisson, France
}

Received: 7 February 2007 - Published in Atmos. Chem. Phys. Discuss.: 1 March 2007

Revised: 27 September 2007 - Accepted: 30 October 2007 - Published: 15 November 2007

Abstract. The mechanism of troposphere-stratosphere exchange in the tropics was investigated from space-borne observations of the horizontal distributions of troposphericorigin long-lived species, nitrous oxide $\left(\mathrm{N}_{2} \mathrm{O}\right)$, methane $\left(\mathrm{CH}_{4}\right)$ and carbon monoxide $(\mathrm{CO})$, from 150 to $70 \mathrm{hPa}$ in March-April-May by the ODIN/Sub-Millimeter Radiometer (SMR), the Upper Atmosphere Research Satellite (UARS)/Halogen Occultation Experiment (HALOE) and the TERRA/Measurements Of Pollution In The Troposphere (MOPITT) instruments in 2002-2004, completed by recent observations of the AURA/Microwave Limb Sounder (MLS) instrument during the same season in 2005. The vertical resolution of the satellite measurements ranges from 2 to $4 \mathrm{~km}$. The analysis has been performed on isentropic surfaces: $400 \mathrm{~K}$ (lower stratosphere) for all the species and 360 $\mathrm{K}$ (upper troposphere) only for CO. At $400 \mathrm{~K}$ (and $360 \mathrm{~K}$ for $\mathrm{CO}$ ), all gases show significant longitudinal variations with peak-to-trough values of $\sim 5-11 \mathrm{ppbv}$ for $\mathrm{N}_{2} \mathrm{O}, 0.07-$ $0.13 \mathrm{ppmv}$ for $\mathrm{CH}_{4}$, and $\sim 10 \mathrm{ppbv}$ for $\mathrm{CO}(\sim 40 \mathrm{ppbv}$ at $360 \mathrm{~K})$. The maximum amounts are primarily located over Africa and, depending on the species, secondary more or less pronounced maxima are reported above northern South America and South-East Asia. The lower stratosphere over the Western Pacific deep convective region where the outgoing longwave radiation is the lowest, the tropopause the highest and the coldest, appears as a region of minimum concentration of tropospheric trace species. The possible impact on trace gas concentration at the tropopause of the inhomogeneous distribution and intensity of the sources, mostly continental, of the horizontal and vertical transports in the troposphere, and of cross-tropopause transport was explored with the MOCAGE Chemistry Transport Model. In the

Correspondence to: P. Ricaud

(philippe.ricaud@aero.obs-mip.fr) simulations, significant longitudinal variations were found on the medium-lived CO (2-month lifetime) with peak-totrough value of $\sim 20 \mathrm{ppbv}$ at $360 \mathrm{~K}$ and $\sim 10 \mathrm{ppbv}$ at $400 \mathrm{~K}$, slightly weaker than observations. However, the $\mathrm{CH}_{4}(8-$ 10 year lifetime) and $\mathrm{N}_{2} \mathrm{O}$ (130-year lifetime) longitudinal variations are significantly weaker than observed: peak-totrough values of $\sim 0.02 \mathrm{ppmv}$ for $\mathrm{CH}_{4}$ and $1-2 \mathrm{ppbv}$ for $\mathrm{N}_{2} \mathrm{O}$ at $400 \mathrm{~K}$. The large longitudinal contrast of $\mathrm{N}_{2} \mathrm{O}$ and $\mathrm{CH}_{4}$ concentrations reported by the space-borne instruments at the tropopause and in the lower stratosphere not captured by the model thus requires another explanation. The suggestion is of strong overshooting over land convective regions, particularly Africa, very consistent with the space-borne Tropical Rainfall Measuring Mission (TRMM) radar maximum overshooting features over the same region during the same season. Compared to observations, the MOCAGE model forced by ECMWF analyses is found to ignore these fast local uplifts, but to overestimate the average uniform vertical transport in the UTLS at all longitudes in the tropics.

\section{Introduction}

The Upper Troposphere-Lower Stratosphere (UTLS) is the atmospheric layer where dynamical, chemical and radiative processes strongly interact to control the atmospheric composition and its impact on climate change. The general characteristics of dynamical processes controlling the UTLS were described in Holton et al. (1995). Air masses brought into the upper troposphere by convection in the tropics enter the lower stratosphere from where they are distributed at global scale by the Brewer-Dobson circulation. However, the still open question is how air masses are transported from the upper troposphere (UT) into the lower stratosphere (LS)

Published by Copernicus Publications on behalf of the European Geosciences Union. 
across the Cold Point Tropopause $(\sim 17 \mathrm{~km}, \sim 100 \mathrm{hPa})$ or the Tropical Transition Layer (TTL), the region of intermediate lapse rate extending from the level of zero net radiative heating (LZH) $(\sim 14 \mathrm{~km}, \sim 150 \mathrm{hPa})$ to the level of stratospheric lapse rate $(\sim 19 \mathrm{~km}, \sim 70 \mathrm{hPa})$. Since the first proposal made by Newell and Gould Stewart (1981) of the existence of strong convective region, the "stratospheric fountain" over the Western Pacific in Micronesia, the Maritime Continent, where the tropopause was recognised to be colder than elsewhere, several mechanisms potentially contributing to Troposphere-Stratosphere Transport (TST), that is transport process from the troposphere to the stratosphere crossing the cold point tropopause, have been identified: i) slow ascent due to radiative heating through the TTL associated with horizontal advection through cold pools playing an important role in dehydrating TTL water vapour to a vapour pressure smaller than would be expected from the zonal mean temperature (e.g. Gettelman et al., 2002; Fueglistaler et al., 2004), ii) convective overshooting and irreversible mixing with the environment above the cold point tropopause, followed by detrainment into the TTL and subsequent radiative ascent (e.g. Sherwood and Dessler, 2000; Dessler, 2002), and iii) convective overshooting directly into the stratosphere (Danielsen, 1993) predominantly above continental areas. However, although the existence of deep convective systems is recognised, they are frequently thought to be of relative little importance at global scale and the slow vertical transport process over the convective Maritime Continent in the Western Pacific, consistent with global-scale meteorological model simulations and supported by the lower Outgoing Longwave Radiation (OLR) on satellite images, is still the generally preferred hypothesis for TST. But, as shown by Alcala and Dessler (2002) from comparisons between thermal imagery and precipitation radar measurements from the Tropical Rainfall Measuring Mission (TRMM) satellite, the OLR is not a good indicator of cloud penetration in the stratosphere. In contrast to the geographical distribution of OLR, the radar indicates higher and more frequent "Overshooting Precipitation Features (OPF)", i.e. echoes above the tropopause, above land areas (Liu and Zipser, 2005), particularly Africa, with a marked diurnal variation peaking in the early afternoon. This picture is consistent with the maximum lightning flashes seen by the Optical Transient Detector instrument onboard the MicroLab-1 satellite, indicative of the fast updraft velocity in the UT (Christian et al., 2003), as well as the afternoon cooling of the TTL recently observed in Brazil during the summer attributed to the injection of adiabatically cooled air above the tropopause up to $19 \mathrm{~km}$ or $440 \mathrm{~K}$ potential temperature level (Pommereau and Held, 2007). According to those results, the maximum penetration of convective systems in the TTL and eventually the lower stratosphere over land areas would occur primarily over Equatorial Africa, South America and Northern Australia during the Austral summer, West Africa, Central America, South-East Asia and the Indonesian Islands during the
Northern summer, but never over Micronesia in the Western Pacific.

The approach proposed here for studying the relative importance of slow/rapid, continental/maritime tropospherestratosphere exchange at global scale is to look at the geographical distribution of tropospheric-origin trace species of different lifetimes in the tropical UTLS. Indeed, if ascent processes slower than horizontal advection around the globe dominate, little variation in the zonal distribution of tropospheric-origin species is expected in the lower stratosphere, as concluded by Levine et al. (2007). In contrast, if fast convective transport processes dominate, the concentration of tropospheric-origin long-lived species in the lower stratosphere should display marked maxima above areas of overshooting, namely energetic convection overshooting the tropopause, possibly modulated by the intensity of the source at surface level.

The geographical distribution of three troposphericorigin trace species available in the upper troposphere and the lower stratosphere from space-borne observations has been studied: nitrous oxide $\left(\mathrm{N}_{2} \mathrm{O}\right)$ from the ODIN/SubMillimeter Radiometer (SMR) and the AURA/Microwave Limb Sounder (MLS), methane $\left(\mathrm{CH}_{4}\right)$ from the Upper Atmosphere Research Satellite (UARS)/Halogen Occultation Experiment (HALOE), and carbon monoxide (CO) from the TERRA/Measurements Of Pollution In The Troposphere (MOPITT) and the AURA/MLS. $\mathrm{N}_{2} \mathrm{O}$ and $\mathrm{CH}_{4}$ are excellent tracers of dynamical processes since their sources are located at the surface (soils, wetlands, biomass burning, industrial exhausts, ...), and their sinks are essentially in the stratosphere through photolysis and chemical reactions with electronically-excited oxygen atoms and $\mathrm{OH}$ (Brasseur et al., 1999). Since their photochemical lifetime decreases from about a century $\left(\mathrm{N}_{2} \mathrm{O}\right)$ or a decade $\left(\mathrm{CH}_{4}\right)$ in the troposphere to less than one year in the middle stratosphere, their concentration drops above the tropopause. While $\mathrm{CO}$, of shorter lifetime, is a good tracer of pollution either from industrial exhaust or from biomass burning, its tropospheric lifetime of the order of two months enables to trace long-range transport of pollution in the horizontal direction within the free troposphere (e.g. Heald et al., 2003) and in the vertical direction through the UTLS (e.g. Li et al., 2005). The CO geographic distribution can help characterizing the seasonal changes in convective outflow (Folkins et al., 2006), and biomass burning via for example the detection of the carbon monoxide tape recorder in the stratosphere (Schoeberl et al., 2006).

Here we focus on the Southern Hemisphere summerspring period in March-April-May (MAM), the season of the circumnavigating long-duration balloon flights in the tropics of the HIBISCUS project with which this study was associated (Pommereau et al., 2007). Besides the spaceborne $\mathrm{N}_{2} \mathrm{O}, \mathrm{CH}_{4}$, and $\mathrm{CO}$ measurements, the study is making use of OLR products from the National Oceanic and Atmospheric Administration (NOAA) Advanced Very High Resolution Radiometer (AVHRR) sensors, fire counts from the 
Visible and IR Scanner (VIRS) instrument onboard TRMM, and temperature, potential temperature, winds and vertical fluxes from the European Center for Medium range Weather Forecasting (ECMWF) over three consecutive years: 2002, 2003 and 2004. The observed distributions of these species will be compared to simulations of a three-dimensional (3D) Chemical Transport Model (CTM) MOCAGE (Modèle de Chimie Atmosphérique à Grande Echelle) covering both the troposphere and the stratosphere.

The paper is organized as follows. After a short description of the measurements, Sect. 2 provides the results of the geographical distribution of the three species near and above the tropopause as seen by the space-borne instruments as well as information on the meteorology of the TTL from ECMWF. After a short description of MOCAGE and of the results of model simulations, Sect. 3 provides a discussion of the influence of the geographical distribution of the sources and the horizontal transport at the surface, of the representation of convection, and mass flux in the model on the longitudinal distribution of the species in the troposphere at the equator. The reasons for the difference between observed and modelled species vertical profiles in the TTL and the LS are discussed in Sect. 4, followed by conclusions in Sect. 5 .

\section{Space-borne observations of tropospheric-origin long-lived species in the TTL}

After a brief description of the ODIN/SMR, UARS/HALOE, TERRA/MOPITT and AURA/MLS, NOAA/AVHRR and TRMM/VIRS measurements and the meteorology of the TTL during the MAM season as seen by ECMWF, this section provides a picture of the geographical distribution of $\mathrm{N}_{2} \mathrm{O}, \mathrm{CH}_{4}$ and $\mathrm{CO}$ in the TTL and the lower stratosphere retrieved from the observations.

\subsection{Satellite data}

\subsubsection{ODIN/SMR $\mathrm{N}_{2} \mathrm{O}$}

The ODIN mini-satellite is a Swedish-led project funded jointly by Sweden, Canada, France, and Finland (Murtagh et al., 2002). It was placed into a 600-km Sun-synchronous, terminator orbit by a START-1 rocket on 20 February 2001, and is still operational. Observing times are equally shared between astronomy and aeronomy. ODIN includes the SMR microwave instrument (Frisk et al., 2003) that can measure ozone $\left(\mathrm{O}_{3}\right)$, chlorine monoxide $(\mathrm{ClO}), \mathrm{N}_{2} \mathrm{O}$, nitric acid $\left(\mathrm{HNO}_{3}\right)$, water vapour $\left(\mathrm{H}_{2} \mathrm{O}\right)$, and $\mathrm{CO}$ in the frequency domain $480-580 \mathrm{GHz}$. Most of the measurements have been validated (e.g. Barret et al., 2006). The present study is based upon the retrievals of the $502.296-\mathrm{GHz} \mathrm{N}_{2} \mathrm{O}$ line measured by Odin/SMR using the Optimal Estimation Method (Rodgers, 2000). On average, measurements of $\mathrm{N}_{2} \mathrm{O}$ are performed one day out of three. In our analysis, we have restricted the $\mathrm{N}_{2} \mathrm{O}$ data set to measurement response greater than 0.75 , i.e. with a minor contribution from a climatology of $\mathrm{N}_{2} \mathrm{O}$ used as a priori. All measurements performed during the period March-May 2002, 2003 and 2004 have been analysed in version V222 of the retrieval algorithm (Urban et al., 2005). The vertical resolution is $2 \mathrm{~km}$. The two layers at 17 and $19 \mathrm{~km}$ where meaningful information can be retrieved are considered. The single scan precision is $\sim 39$ and $\sim 24 \mathrm{ppbv}(\sim 10-12 \%)$ at 17 and $19 \mathrm{~km}$, respectively and the total systematic error is $\sim 22$ and $\sim 13$ ppbv ( $\sim 4-6 \%)$ at 17 and $19 \mathrm{~km}$, respectively. Measurements have been averaged into bins of $10^{\circ}$ latitude $\times 30^{\circ}$ longitude.

\subsubsection{AURA/MLS $\mathrm{N}_{2} \mathrm{O}$ and $\mathrm{CO}$}

The MLS sounder is one of the four instruments onboard the Earth Observing System (EOS) AURA satellite launched on 15 July 2004 in a Sun-synchronous orbit ( $98^{\circ}$ inclination) at $\sim 705 \mathrm{~km}$ altitude with an ascending node at 13:45 hours (local time). Vertical profiles of 17 target atmospheric parameters, among which 14 trace gases, are retrieved from MLS observations with a $165-\mathrm{km}$ horizontal spacing along the orbit track (Waters et al., 2006). The retrieval method, also based on the Optimal Estimation Method, is described by Livesey et al. (2006). The new concept implemented in the MLS retrieval algorithm is a 2-D approach allowing retrieval of atmospheric structures in both the vertical and line-ofsight directions taking into account the overlapping regions covered by consecutive scans. A detailed description of the MLS version 1.5 products used in the present study can be found in the "EOS MLS Version 1.5 Level 2 data quality and description document" (Livesey et al., 2005). First results from CO measured by MLS are described in Filipiak et al. (2005). CO profiles are retrieved with a single-scan precision of $\sim 20 \mathrm{ppbv}$ in the domain $215-22 \mathrm{hPa}(\sim 20 \%$ at $150 \mathrm{hPa}, \sim 30 \%$ at $100 \mathrm{hPa}$ and $\sim 45 \%$ at $70 \mathrm{hPa}$ ) and a vertical resolution of $\sim 4 \mathrm{~km}$ in the upper-troposphere and the lower stratosphere (Froidevaux et al., 2006). The $\mathrm{N}_{2} \mathrm{O}$ retrievals are considered useful from 100 to $1 \mathrm{hPa}$ with a vertical resolution of $\sim 4 \mathrm{~km}$. The precision is estimated to $\sim 30 \mathrm{ppbv}(\sim 10 \%)$ at the $100 \mathrm{hPa}$ and $70 \mathrm{hPa}$ levels (Froidevaux et al., 2006). MLS $\mathrm{N}_{2} \mathrm{O}$ and $\mathrm{CO}$ data have been averaged within bins of $10^{\circ}$ latitude $\times 30^{\circ}$ longitude. For $\mathrm{N}_{2} \mathrm{O}$, measurements at two altitude levels, 100 and $70 \mathrm{hPa}$, are being considered, while three levels are used for CO: 150-, 100-, and 70-hPa.

\subsubsection{UARS/HALOE $\mathrm{CH}_{4}$}

The HALOE instrument onboard the UARS satellite measured $\mathrm{CH}_{4}$ from October 1991 to November 2005 (Russell et al., 1993). The geometry of the UARS orbit (57 inclination, circular at $585 \mathrm{~km}$ with orbit period of $96 \mathrm{~min}$ ) results in about 15 sunrises and 15 sunsets daily, with tangent point locations during a day confined to small latitude bands, different for the two events, which cycle over varying extremes, 


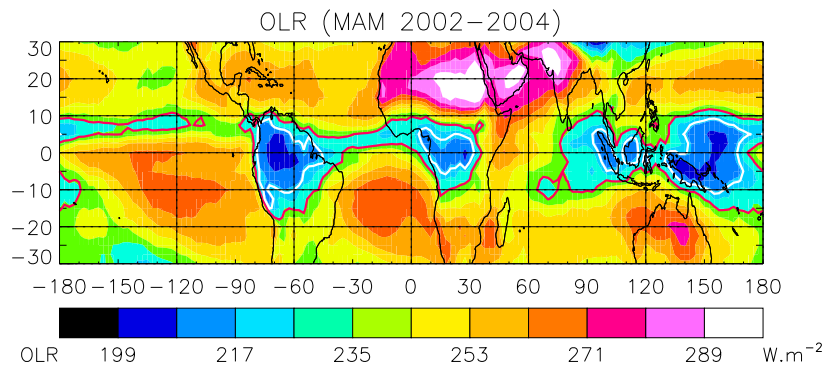

Fig. 1. AVHRR mean Outgoing Longwave radiation $\left(\mathrm{OLR}, \mathrm{Wm}^{-2}\right)$ in MAM 2002-2004. Red line: $236 \mathrm{Wm}^{-2}$; white line: $220 \mathrm{Wm}^{-2}$.

roughly every 36 days. As for Odin, data have been averaged into bins of $10^{\circ}$ latitude $\times 30^{\circ}$ longitude and linearly interpolated onto the $17-\mathrm{km}$ and $19-\mathrm{km}$ altitude layers. This corresponds to 2-10 vertical profiles available per bin in the equatorial region from 100 to $60 \mathrm{hPa}$ during the period MAM 2002-2004 and more than 10 during the period MAM 19922005. Indeed, we have also used the entire HALOE data set Version 19 available during the period MAM in order to cope for any problems in the measurements at the end of the instrument's activity and increasing the signal-to-noise ratio. For the analysis presented here, only profiles with uncertainties less than $100 \%$ have been included. In addition, as suggested in Park et al. (2004), we have considered only $\mathrm{CH}_{4}$ mixing ratios less than 2 ppmv. The total error including systematic and random uncertainty for individual profiles of $\mathrm{CH}_{4}$ is $20 \%$ (Park et al., 1996) in the $50-100 \mathrm{hPa}$ domain whilst the precision (including random error) is $\sim 7 \%$. The vertical resolution is $\sim 2-3 \mathrm{~km}$.

\subsubsection{TERRA/MOPITT CO}

The TERRA/MOPITT instrument (Drummond and Mand, 1996) has been monitoring global tropospheric CO from March 2000 to date. These data have been intensively validated (e.g. Barret et al., 2003; Emmons et al., 2004 and 2007). The pixel size is $22 \mathrm{~km} \times 22 \mathrm{~km}$ and the vertical profiles are retrieved on 7 pressure levels (surface, 850, 700, 500, 350,250 and $150 \mathrm{hPa}$ ). The maximum likelihood method used to retrieve the MOPITT CO is a statistical combination of the measurements and a priori information (Rodgers, 2000). The retrieval profiles are characterized by their averaging kernels providing information on the vertical resolution of the measurements. The Degree of Freedom for Signal (DFS), which is the trace of the averaging kernel matrix, indicates the number of independent pieces of information contained in the measurements. It depends, via the surface temperature, on the latitude and the alternating day/night. During daytime over the tropics, the zonal average DFS is about 1.5 (Deeter et al., 2004); this insures that MOPITT provides almost two independent pieces of information located in the lower and in the upper troposphere. In this study, we only consider daytime MOPITT CO (Version 3) retrievals at 850 and $150 \mathrm{hPa}$ with less than $40 \%$ a priori contamination and a total error of $\sim 20 \%$ on each pixel. MOPITT CO data have been averaged within bins of $0.5^{\circ} \times 0.5^{\circ}$.

\subsubsection{NOAA/AVHRR OLR}

OLR is measured by the NOAA/AVHRR. Interpolated data (Liebmann and Smith, 1996) are taken from the NOAACIRES Climate Diagnostics Centre web site http://www.cdc. noaa.gov, from the NOAA 16 series of satellites. Data are binned within boxes of $2.5^{\circ}$ latitude $\times 2.5^{\circ}$ longitude. The OLR is a measure of the thermal infrared radiation that escapes from the top of the Earth's atmosphere back into space. Cumulonimbus clouds, representative of deep convection, have high and cold tops and they radiate little longwave radiation to outer space. Regions with low OLR are therefore associated with deep convection. OLR data have been averaged over the MAM 2002-2004 period. Areas of OLR with values less than 236 and $220 \mathrm{~W} \mathrm{~m}^{-2}$ can be considered as an estimation of the convective outflow location in the middle $(\sim 400 \mathrm{hPa})$ and in the upper $(\sim 100 \mathrm{hPa})$ tropical troposphere, respectively.

\subsubsection{TRMM/VIRS fire counts}

The location of fire counts is provided by the VIRS instrument onboard TRMM. The VIRS is a 5-channel cross-track scanning radiometer that measures radiance in five bandwidths from the visible through the infrared spectral regions: $0.63,1.6,3.75,10.80$, and $12.0 \mu \mathrm{m}$ at $2 \mathrm{~km}$ horizontal resolution (Giglio et al., 2000). Although the VIRS instrument is designed primarily to study clouds and precipitation, it is capable of spotting active fires as well as evidence of burn scars. The TRMM/VIRS 4- $\mathrm{km}^{2}$ Fire Product shows the number of $4.4 \mathrm{~km}^{2}$ pixels in each half-degree grid cell (each cell is 2500 square kilometres at the equator) that are hot enough to contain a large fire.

\subsection{TTL meteorology in March-April-May}

Before looking at the distribution of trace gases, this paragraph provides a picture of the meteorology of the TTL during the MAM season. Figure 1 shows the mean OLR derived from AVHRR and Fig. 2 the average meteorological fields from ECMWF analyses during the period: temperature at $17 \mathrm{~km}(\sim 94 \mathrm{hPa})$; potential temperature at the same altitude level; height of the $370-\mathrm{K}$ isentropic surface, roughly the tropopause; and horizontal winds at $17 \mathrm{~km}$.

As shown by Fig. 1, the lowest OLR are located primarily over the Western Pacific (Micronesia), then Amazonia in South America followed by Equatorial Africa and Indonesian Islands. The thin tongues of low OLR over the Atlantic and the Eastern Pacific correspond to the Inter Tropical Convergence Zone (ITCZ). Note that this is in contrast with 
the average 1998-2003 distribution of Overshoot Precipitation Features (OPF) for the same season provided by the TRMM radar (Liu and Zipser, 2005), displaying a maximum first over Equatorial Africa and then, of lesser amplitude, over South America and Indonesian Islands, but not over the Western Pacific. As discussed by Sherwood et al. (2004), OLR is an indicator of cloud top temperature but not directly of their height or of the amplitude of convection. Indeed, as pointed out by Alcala and Dessler (2002), continental convection is more efficient than oceanic convection for overshootings to reach the TTL, though, part of the disagreement between the OLR and OPF pictures could come also from the smoothing in the OLR averages of the diurnal modulation of land convection more developed in the early afternoon, compared to the small amplitude of diurnal cycle of oceanic convection (Liu and Zipser, 2005).

As shown in Fig. 2, the potential temperature at $17 \mathrm{~km}$ is the lowest over the Western Pacific but the highest over Africa and South America, meaning that the tropopause defined as the $370-\mathrm{K}$ surface (Fig. 2c) is on average $0.6 \mathrm{~km}$ higher over the Western Pacific than over the convective African and American continents. Since an air parcel moving adiabatically along the $370-\mathrm{K}$ surface will be uplifted above Western Pacific compared to land areas, the concentration at constant altitude of a tropospheric-origin trace species should be larger over the Western Pacific than over continents. Another feature of interest for trace species distribution shown in Fig. 2d, is the zonal wind divergence at the equator at $17 \mathrm{~km}$ over the Western Pacific and the convergence over Africa and South America, corresponding to the upper branch of the Walker circulation.

\subsection{Horizontal distribution in the TTL}

The geographical distributions of $\mathrm{N}_{2} \mathrm{O}, \mathrm{CH}_{4}$, and $\mathrm{CO}$ in the tropical UTLS are available at three levels: i) at $19 \mathrm{~km}$ $(66 \mathrm{hPa})$ for SMR and HALOE or $70 \mathrm{hPa}(18.7 \mathrm{~km})$ for MLS in the lower stratosphere, ii) at $17 \mathrm{~km}(94 \mathrm{hPa})$ for SMR and HALOE and $100 \mathrm{hPa}(16.6 \mathrm{~km})$ for MLS, around the tropopause and iii) at $150 \mathrm{hPa}(14.2 \mathrm{~km})$ for MLS and MOPITT CO in the UT. Note that since the tropopause height varies in longitude, the $17 \mathrm{~km} / 100 \mathrm{hPa}$ level is below the tropopause over the Western Pacific but above it over continents. For removing the impact of the longitudinal as well as the latitudinal change of height of potential temperature surfaces, trace gases measurements have been linearly interpolated on the 400-K surface (approximately $1.5 \mathrm{~km}$ above the tropopause) for all the species, and on the $360-\mathrm{K}$ surface (approximately $1.5 \mathrm{~km}$ below the tropopause) for MLS $\mathrm{CO}$. Keeping in mind the coarse vertical resolution of the satellite data (ranging from $\sim 2$ to $\sim 4 \mathrm{~km}$ ) in the UTLS, we assume that the averaging kernels 1) peak at the considered altitude/pressure and 2) are symmetrical with respect to the peak along the vertical.

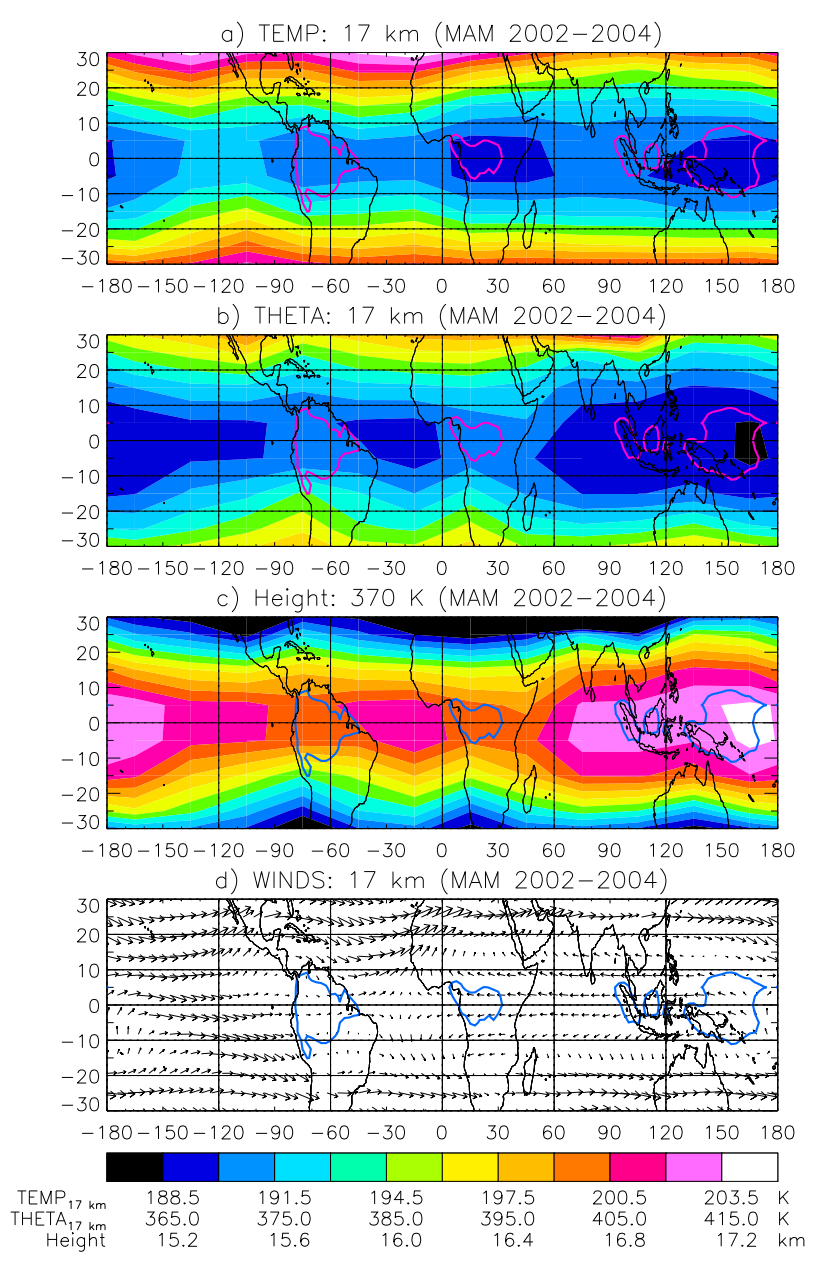

Fig. 2. Mean ECMWF meteorological parameters in the TTL in MAM 2002-2004. From top to bottom: (a) temperature at $17 \mathrm{~km}$; (b) potential temperature at $17 \mathrm{~km}$; (c) $370-\mathrm{K}$ potential temperature surface height; and (d) horizontal wind direction and speed at $17 \mathrm{~km}$.

SMR $\mathrm{N}_{2} \mathrm{O}$ mixing ratios at 19 and $17 \mathrm{~km}$ and in between at $400 \mathrm{~K}$ (approximately $18.5 \mathrm{~km}$ ) are displayed in Fig. 3, MLS $\mathrm{N}_{2} \mathrm{O}$ at $70 \mathrm{hPa}, 400 \mathrm{~K}$ and $100 \mathrm{hPa}$ in Fig. 4, HALOE $\mathrm{CH}_{4}$ for 2002-2004 and 1992-2005 at $19 \mathrm{~km}, 400 \mathrm{~K}$ and $17 \mathrm{~km}$ in Figs. 5 and 6, respectively, MLS CO at $70 \mathrm{hPa}, 400 \mathrm{~K}$ and $100 \mathrm{hPa}$ in Fig. 7, and MLS CO at $360 \mathrm{~K}, 150 \mathrm{hPa}$ and MOPITT CO at $150 \mathrm{hPa}$ in Fig. 8 . We have indeed retained the fixed altitude/pressure maps for reference as they are the observed quantities, but will hereafter discuss the behaviour of atmospheric constituents on isentropic surfaces.

The ODIN $\mathrm{N}_{2} \mathrm{O}$ field at $400 \mathrm{~K}$ (Fig. 3) shows a long band of enhanced concentration between $10^{\circ} \mathrm{S}-10^{\circ} \mathrm{N}$ extending from South America to South-East Asia with a pronounced maximum ( 2316 ppbv) over Equatorial Africa and a slight maximum over South America and Indonesia ( $310 \mathrm{ppbv})$. The amplitude of the contrast between high and low mixing ratios (hereafter referred to as the peak-to-trough value) is 


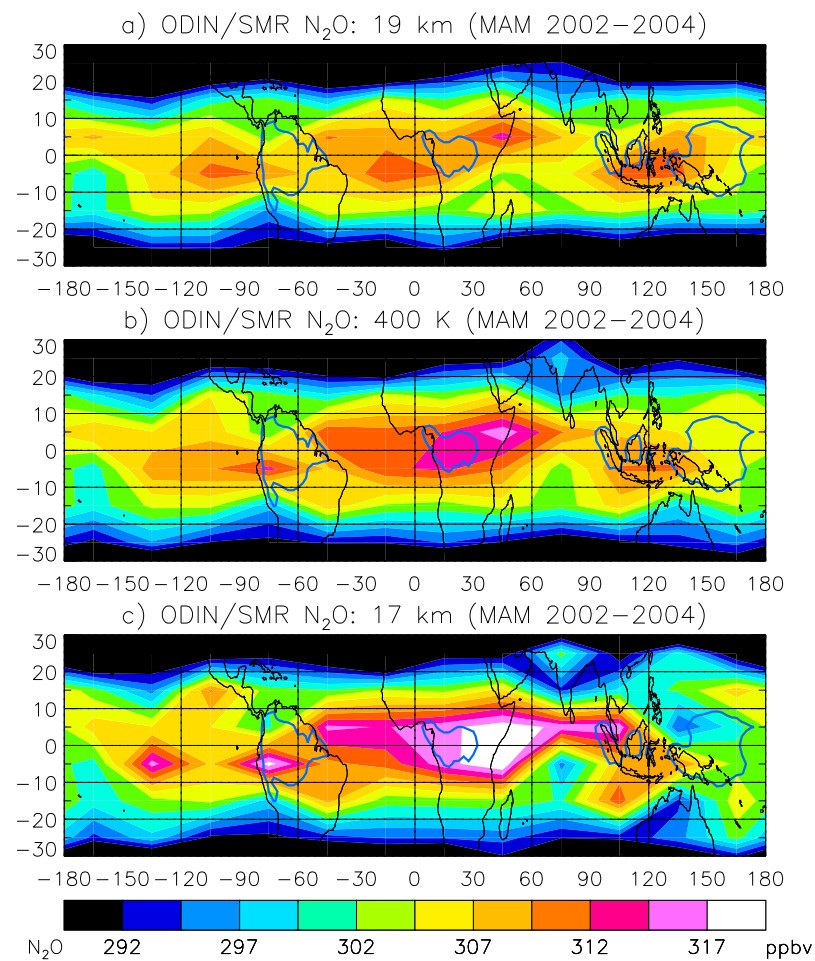

Fig. 3. ODIN/SMR $\mathrm{N}_{2} \mathrm{O}$ mixing ratio in MAM 2002-2004 at $19 \mathrm{~km}$ (top) and $17 \mathrm{~km}$ (bottom), and interpolated at $400 \mathrm{~K}$ (middle panel). Blue line: OLR $220 \mathrm{~W} \mathrm{~m}^{-2}$.

of about $11 \mathrm{ppbv}$ at $400 \mathrm{~K}$ and still present above at $19 \mathrm{~km}$ ( $\sim 8 \mathrm{ppbv}$ ). The $400-\mathrm{K}$ peak-to-trough value is significantly larger than the averaged random error of about 3 ppbv.

Compared to ODIN, and despite its lower vertical resolution of $4 \mathrm{~km}$ instead of $2 \mathrm{~km}$, the MLS version $1.5 \mathrm{~N}_{2} \mathrm{O}$ fields in MAM 2005 (Fig. 4) are high biased by about 13.5 ppbv at $100 \mathrm{hPa}$ and low biased by $6-8 \mathrm{ppbv}$ at $70 \mathrm{hPa}$. Indeed, the $100-\mathrm{hPa} \mathrm{N}_{2} \mathrm{O}$ mixing ratios from MLS appear much greater than the expected 320 ppbv of $\mathrm{N}_{2} \mathrm{O}$ generally accepted in the troposphere from surface data, and the 70-hPa $\mathrm{N}_{2} \mathrm{O}$ from MLS produces an unrealistic vertical change of $\sim 30 \mathrm{ppbv}$ in the 100-70 hPa layer. Consequently, because of the fixed colour table used, we have decided to arbitrarily represent in Fig. 4 the $\mathrm{N}_{2} \mathrm{O}$ fields from MLS scaled by $+13.5 \mathrm{ppbv}$ at $70 \mathrm{hPa}$ and by $-13.5 \mathrm{ppbv}$ at $100 \mathrm{hPa}$. Nevertheless, the MLS $\mathrm{N}_{2} \mathrm{O}$ field at $400 \mathrm{~K}$ still displays a maximum over Africa with a smaller peak-to-trough value: $5 \mathrm{ppbv}$ for MLS (average random noise of $\sim 0.7 \mathrm{ppbv}$ ) instead of $\sim 11 \mathrm{ppbv}$ for ODIN.

The HALOE $\mathrm{CH}_{4}$ fields in 2002-2004 (Fig. 5) also display a maximum at $400 \mathrm{~K}$ over Africa of about $1.73 \mathrm{ppmv}$ and a secondary one over Indonesia extending north to SouthEast Asia, with a longitudinal peak-to-trough value of about 0.13 ppmv (average random noise of $0.05 \mathrm{ppmv}$ ). During the 1992-2005 period (Fig. 6), a maximum of $\mathrm{CH}_{4}$ is still present at $400 \mathrm{~K}$ over Central Africa $(\sim 1.70 \mathrm{ppmv})$ but of a lesser

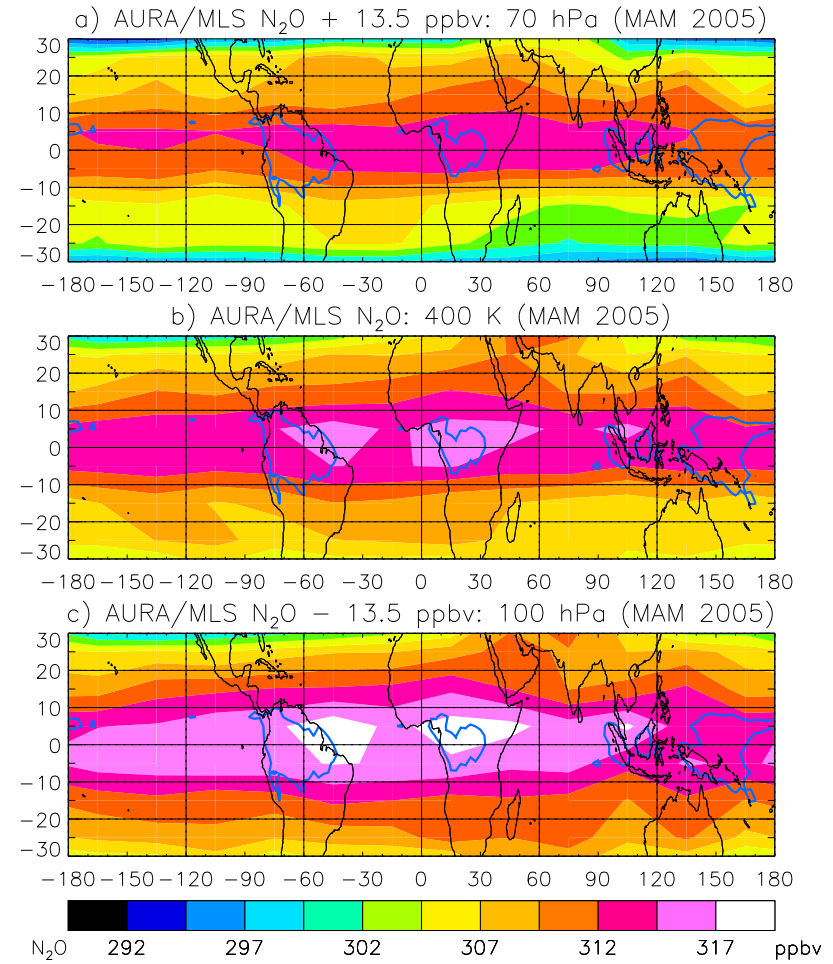

Fig. 4. Same as Fig. 3 but for AURA/MLS $\mathrm{N}_{2} \mathrm{O}$ in MAM 2005 at (a) $70 \mathrm{hPa}$, approx. $18.7 \mathrm{~km}$, (b) $400 \mathrm{~K}$ and (c) $100 \mathrm{hPa}$, approx. $16.6 \mathrm{~km}$. Note that the MLS $\mathrm{N}_{2} \mathrm{O}$ field has been shifted by $+13.5 \mathrm{ppbv}$ at $70 \mathrm{hPa}$ and by $-13.5 \mathrm{ppbv}$ at $100 \mathrm{hPa}$ in order to be visible using the fixed colour table.

amplitude compared to the 2002-2004 period. The standard deviation of the HALOE data in the Equatorial band $\left(10^{\circ} \mathrm{S}-\right.$ $10^{\circ} \mathrm{N}$ ) is about 0.05 ppmv during the 2002-2004 period increasing to $0.08 \mathrm{ppmv}$ during the longer 1992-2005 period. The peak-to-trough value is also weaker in 1992-2005 compared to 2002-2004: $\sim 0.07$ ppmv (average random noise: $\sim 0.03$ ppmv).

Finally, the MLS CO fields in MAM 2005 also show a strong feature over Africa at $400 \mathrm{~K}$ (Fig. 7) and $360 \mathrm{~K}$ (Fig. 8), but in contrast to previous species, extending to the tropical South-East Asia. Also remarkable compared to other species is the fast decrease of maximum mixing ratios $(110 \mathrm{ppbv}$ at $360 \mathrm{~K}$ and $60 \mathrm{ppbv}$ at $400 \mathrm{~K})$ and longitudinal peak-to-trough values at increasing altitude: $40 \mathrm{ppbv}$ at $360 \mathrm{~K}$ (average random error: $\sim 0.35 \mathrm{ppbv}$ ) and $\sim 10 \mathrm{ppbv}$ at $400 \mathrm{~K}$ (average random noise: $\sim 0.35 \mathrm{ppbv}$ ). On pressure levels, the MOPITT CO field at $150 \mathrm{hPa}$ in 2002-2004 also shows a maximum over Africa but of a weaker intensity compared to MLS CO at $150 \mathrm{hPa}(90 \mathrm{ppbv}$ for MOPITT instead of $130 \mathrm{ppbv}$ for MLS). The longitudinal peak-totrough value between the Western Pacific and Africa reaches $\sim 30$ ppbv (average random error $\sim 0.10 \mathrm{ppbv}$ ) in MOPITT against $\sim 45 \mathrm{ppbv}$ (average random error $\sim 0.35 \mathrm{ppbv}$ ) in 


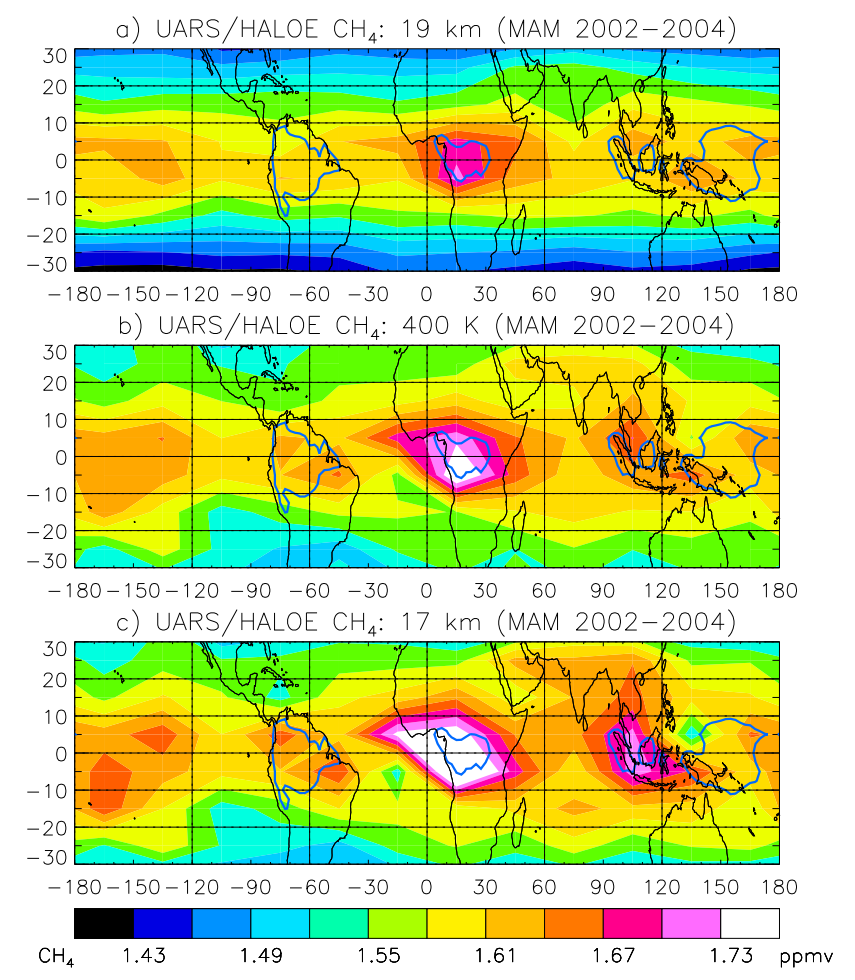

Fig. 5. Same as Fig. 3 but for UARS/HALOE $\mathrm{CH}_{4}$ in MAM 20022004 at $19 \mathrm{~km}$ (top), and $17 \mathrm{~km}$ (bottom), and interpolated at $400 \mathrm{~K}$.

MLS at $150 \mathrm{hPa}$. A secondary maximum (70 ppbv) is observed in the MOPITT CO field over the tropical North-West Pacific whilst not detected in the CO MLS field. These differences might come from the different observing geometries of the two instruments affecting the vertical resolution, the nadir-viewing MOPITT being more sensitive in the mid-toupper troposphere whilst the sensitivity of the limb-viewing MLS is peaking in the UTLS. Another explanation could be the differences in CO source intensities between 2005 (MLS) and 2002-2004 (MOPITT) periods, related to the large variability of biomass burning as well as increasing pollution in South-East Asia.

\subsection{Discussion}

Overall, though of very different lifetimes, the three tropospheric-origin gas species do show an equatorial belt in the UT/LS confined between the Subtropical Westerly Jets (SWJ) with a maximum mixing ratio between $100^{\circ} \mathrm{W}$ and $100^{\circ}$ E over the western hemisphere, particularly pronounced over Africa and to a lesser extend over South America and South-East Asia. The preferred location of maxima over continents, coincident with convergent regions of the upper branch of the Walker circulation, better match the maximum TRMM radar OPF frequency indicative of convective overshooting than the AVHRR minimum OLR indicative of coldest cloud top temperature. The area of the "Stratospheric

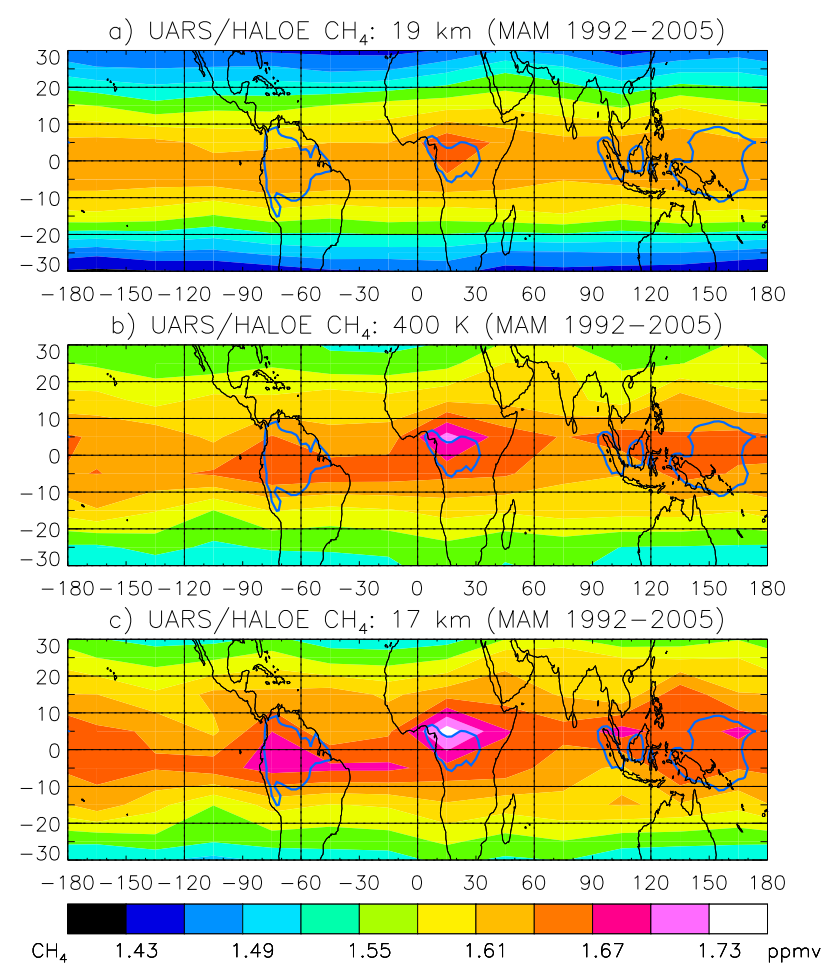

Fig. 6. Same as Fig. 3 but for UARS/HALOE $\mathrm{CH}_{4}$ in MAM 19922005 at (a) $19 \mathrm{~km}$, (b) $400 \mathrm{~K}$ and (c) $17 \mathrm{~km}$.

Fountain" over Micronesia never appears as an enriched region. However, the geographical distribution of the maximum mixing ratio varies with the species. The African maximum is a persistent feature on all of them. $\mathrm{N}_{2} \mathrm{O}$ displays secondary maxima over South America and Indonesian Islands, less pronounced in $\mathrm{CH}_{4}$ and almost absent in $\mathrm{CO}$ over South America. Furthermore, CO shows an increased abundance up to $70 \mathrm{hPa}$ over South-East Asia not seen on other gases. Although the location of the larger amounts in the lower stratosphere coincides with that of strong land convective areas as well as convergent regions of the upper branch of the Walker circulation, this could indicate also a significant impact of the geographic distribution of sources, known to be continental for the three gases. The possible relative influence of source distribution, horizontal and vertical transport and convection have been explored using a CTM model.

\section{Model simulations}

This section deals with simulations of $\mathrm{N}_{2} \mathrm{O}, \mathrm{CH}_{4}$ and $\mathrm{CO}$ in the troposphere and the lower stratosphere to see how well the observed distributions of the species could be captured by the model and what are the most important parameters influencing them. 

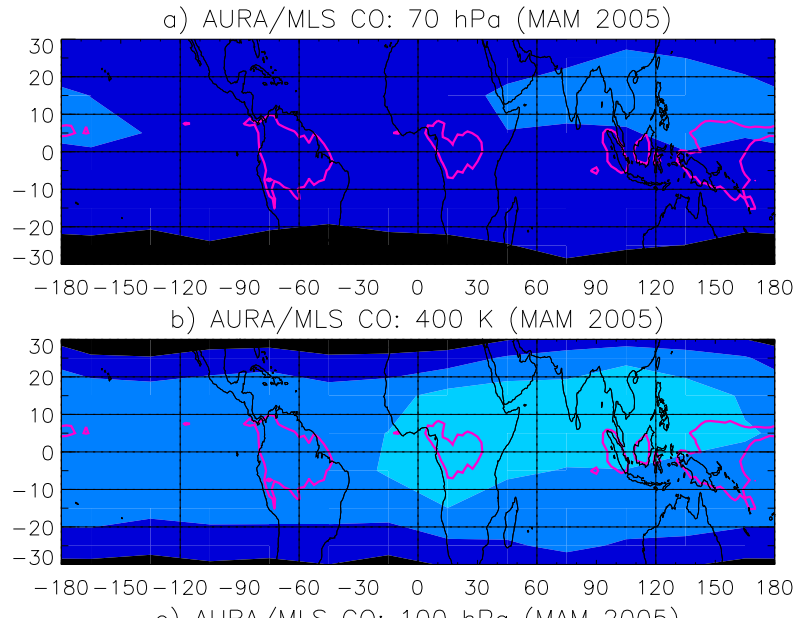

c) AURA/MLS CO:100 hPg (MAM 2005$)$

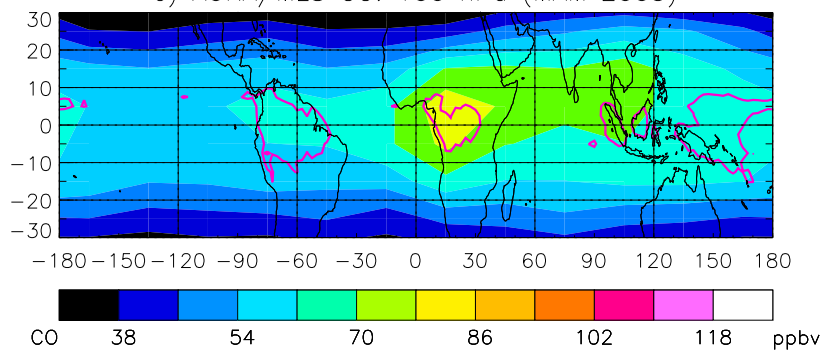

Fig. 7. Same as Fig. 3 but for AURA/MLS CO in MAM 2005 at (a) $70 \mathrm{hPa}$, (b) $400 \mathrm{~K}$ and (c) $100 \mathrm{hPa}$.

\subsection{Model description}

MOCAGE-Climat (Teyssèdre et al., 2007) is the climate version of Météo-France's tropospheric-stratospheric 3-D CTM MOCAGE. MOCAGE covers a range of scientific applications, from the study of climate-chemistry interactions to chemical data assimilation and "chemical weather" forecasting. The MOCAGE model can use different horizontal resolutions with semi-Lagrangian advection scheme (Josse et al., 2004) and parameterizations for physical processes such as convection (Betchold et al., 2001) and surface processes (Michou et al., 2004). The climate version used in the present study covers both the troposphere and the stratosphere, with 60 layers from the surface up to $0.07 \mathrm{hPa}$, and uses a Gaussian T21 $\left(5.8^{\circ} \times 5.8^{\circ}\right)$ horizontal grid. The meteorological forcing from ECMWF constrains the model from 1 January 2000 to 31 December 2005, relying on the archived 6-hourly operational analyses of winds, temperature and specific humidity, to resolve both the general atmospheric circulation, and to drive parameterizations of subscaled processes. The vertical wind in the UTLS is that of the residual circulation in the ECMWF analyses which, as all numerical models, systematically overestimate the vertical transport in the tropics (Waugh and Hall, 2002; Teyssèdre et al., 2007). Chemistry used within MOCAGE-Climat is a combination of tropospheric (Crassier et al., 2000) and

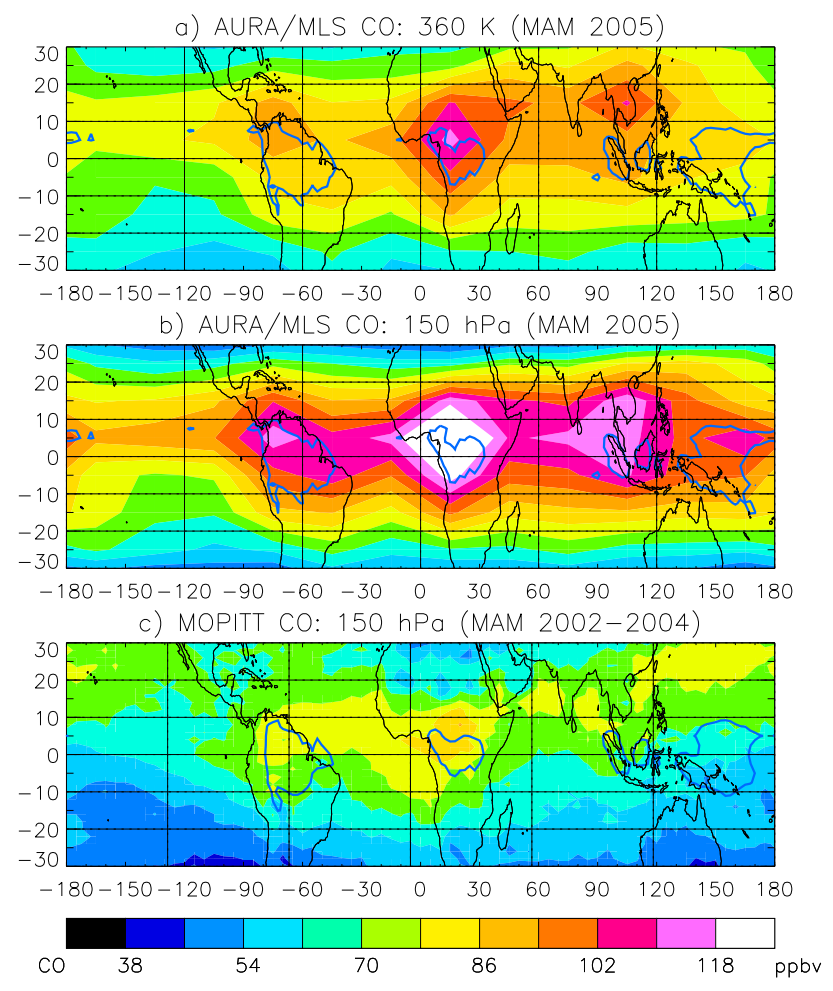

Fig. 8. From top to bottom: MLS CO at $360 \mathrm{~K}$ and $150 \mathrm{hPa}$ in MAM 2005 and MOPITT CO at $150 \mathrm{hPa}$ in MAM 2002-2004.

stratospheric (Lefèvre et al., 1994) chemical schemes, taking into account 83 species and 242 chemical reactions. Initial chemical conditions are taken from a previous simulation (WMO, 1998) to allow the model to quickly bring chemical fields to realistic spatial distributions, especially for long-lived species such as $\mathrm{N}_{2} \mathrm{O}$ and $\mathrm{CH}_{4}$. Surface emissions prescribed in MOCAGE-Climat are based upon yearly- or monthly-averaged climatologies. The $\mathrm{N}_{2} \mathrm{O}$ surface emissions are taken from the Global Emissions Inventory Activity and are representative of year 1990 (Bouwman et al., 1995). They include anthropogenic and biogenic sources, for a total emission rate of $14.7 \mathrm{Tg}(\mathrm{N}) \mathrm{yr}^{-1}$. The $\mathrm{CH}_{4}$ surface emissions are split into anthropogenic sources taken from the Intergovernmental Panel on Climate Change (Dentener et al., 2005), biomass burning (van de Werf et al., 2003) and biogenic sources (Michou and Peuch, 2002). The $\mathrm{CH}_{4}$ climatologies are representative of year 2000 for a total emission rate of $534 \mathrm{Tg}\left(\mathrm{CH}_{4}\right) \mathrm{yr}^{-1}$. The CO surface emissions are split into anthropogenic (including biomass burning) sources from Dentener et al. (2005) and biogenic sources as prescribed in the MOZART CTM (L. Emmons and J.-F. Lamarque, private communication). The $\mathrm{CO}$ climatologies are representative of year 2000, for a total emission rate of $1122 \mathrm{Tg}(\mathrm{CO}) \mathrm{yr}^{-1}$. For more information on surface emissions, the reader should refer to Dentener et al. (2005). Finally, MOCAGE-Climat provides a comprehensive description of the chemical processes 

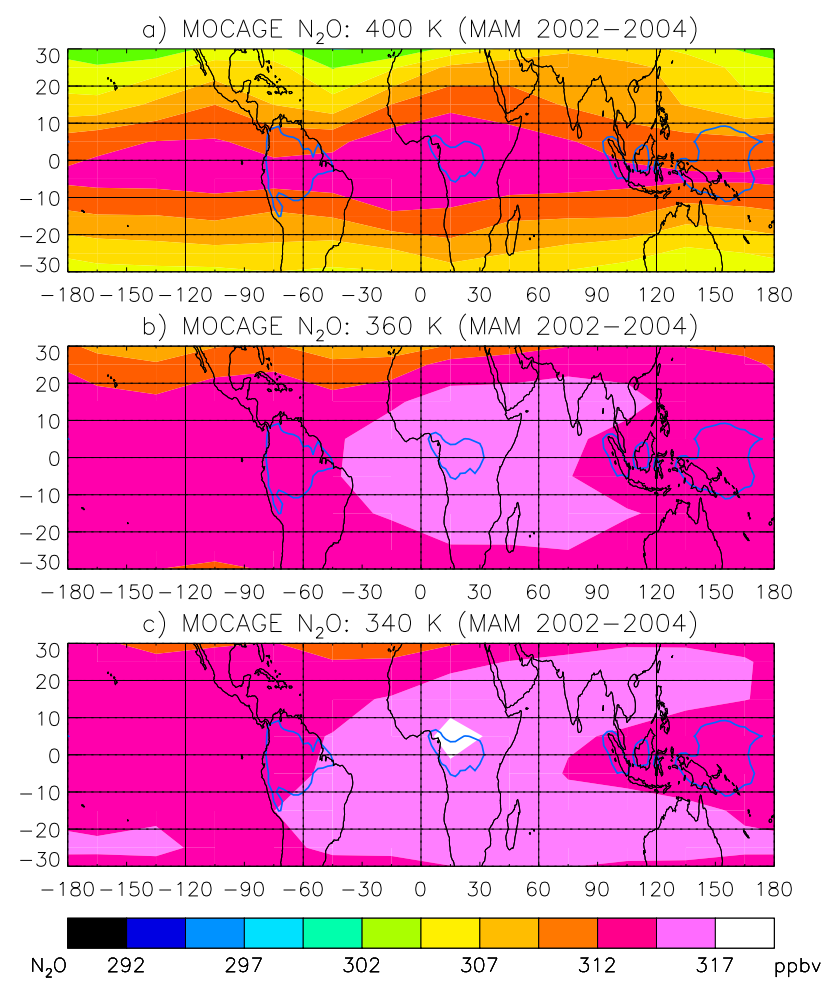

Fig. 9. $\mathrm{N}_{2} \mathrm{O}$ fields simulated by MOCAGE in the TTL at (a) 400, (b) 360 and (c) $340 \mathrm{~K}$ in MAM 2002-2004.

in the planetary boundary layer, free troposphere and stratosphere, adapted to the processes studied here.

Regarding convection, two schemes can be used. Both are mass flux schemes. The first is a simplified version of Tiedtke (1989) where downdrafts, inside-cloud subsidence, and organized entrainment above cloud base are neglected. Penetrating convection is assumed to occur when both a deep layer of conditional instability and a large-scale moisture convergence exist (therefore implying surrounding columns influences). The second scheme is that of Betchold et al. (2001). It is also a mass flux scheme, but the parameterization is slightly more complex than Tiedtke's, as downdrafts, freezing and melting are considered. Calculations are made for a single column (i.e., no influence of neighbouring columns). Convection is activated or not by evaluating a single air parcel that is lifted from the ground to its condensation level. Contrarily to the Tiedtke scheme, scavenging (below and inside cloud, for both stratiform and convective clouds) is taken into account when using Betchold scheme. This is of primary importance for long-term simulations of chemical species that are soluble (such as nitric acid). More details about these convection schemes used within MOCAGE, and validation results when simulating ${ }^{222} \mathrm{Rn}$ and ${ }^{210} \mathrm{~Pb}$ fields, can be found in Josse et al. (2004) who obtained realistic fields compared to observations. This latter study confirmed earlier results from Rasch et al. (1997) showing

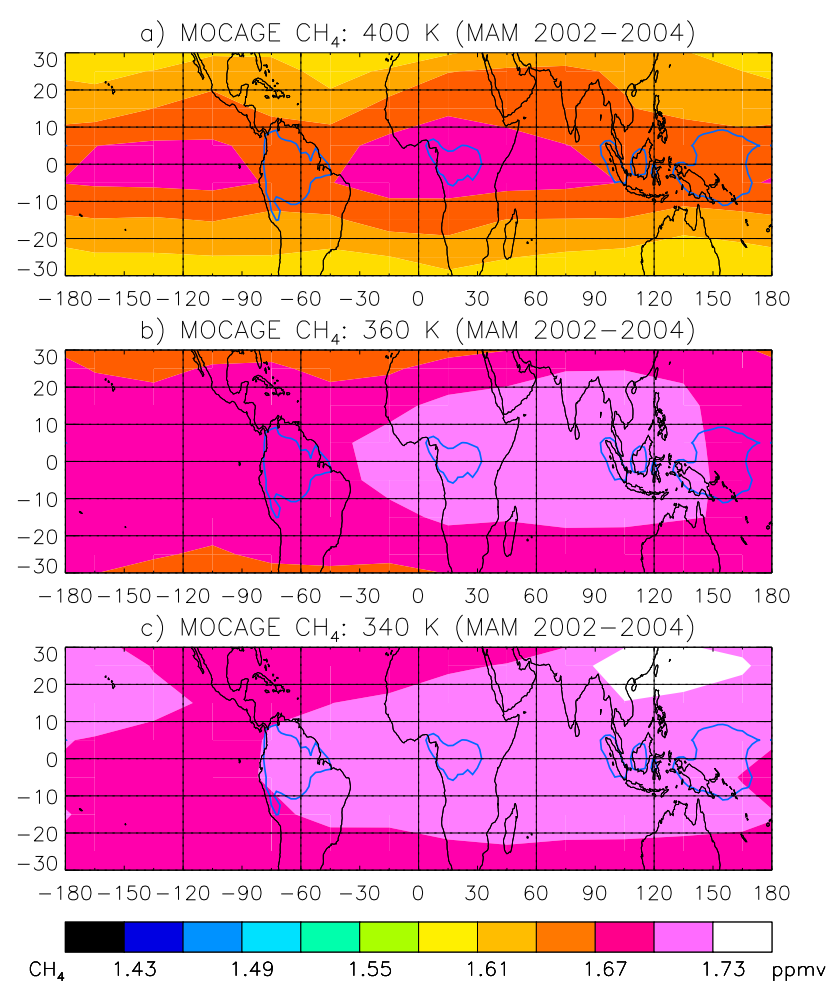

Fig. 10. Same as Fig. 9 but for $\mathrm{CH}_{4}$.

that the use of 6-hourly meteorological fields to force "offline" CTMs (such as MOCAGE) is sufficient to accurately represent transport processes, leading to small errors compared to "on-line" model calculations, even in case of rapid transport processes. The present run was performed using the Betchold scheme. Finally, note there is no parameterization of overshoot processes in the model.

\subsection{Trace gas horizontal distribution in the TTL}

Although MOCAGE vertical grid is in pressure coordinates, we will use potential temperature as vertical coordinates for: i) reducing the number of figures (note that the reference vertical grid for the measurements is either pressure or altitude); ii) being consistent with observed fields interpolated at $360 \mathrm{~K}$ and/or $400 \mathrm{~K}$; and iii) interpret the processes within three well defined layers: at $340 \mathrm{~K}$ in the upper troposphere, at $360 \mathrm{~K}$ near the tropopause, and $400 \mathrm{~K}$ in the lower stratosphere. The trace gas distributions simulated by MOCAGE at three isentropic levels $(400 \mathrm{~K}, 360 \mathrm{~K}$ and $340 \mathrm{~K})$ for the MAM season in 2002-2004 averaged within bins of $10^{\circ}$ latitude and $30^{\circ}$ longitude, are shown in Fig. $9\left(\mathrm{~N}_{2} \mathrm{O}\right)$, Fig. 10 $\left(\mathrm{CH}_{4}\right)$ and Fig. $11(\mathrm{CO})$.

Consistent with ODIN and MLS observations (Figs. 3 and 4), the MOCAGE $\mathrm{N}_{2} \mathrm{O}$ simulations do show larger amounts in the upper troposphere near the tropopause over Africa compared to the Pacific, but in contrast to observations, no 


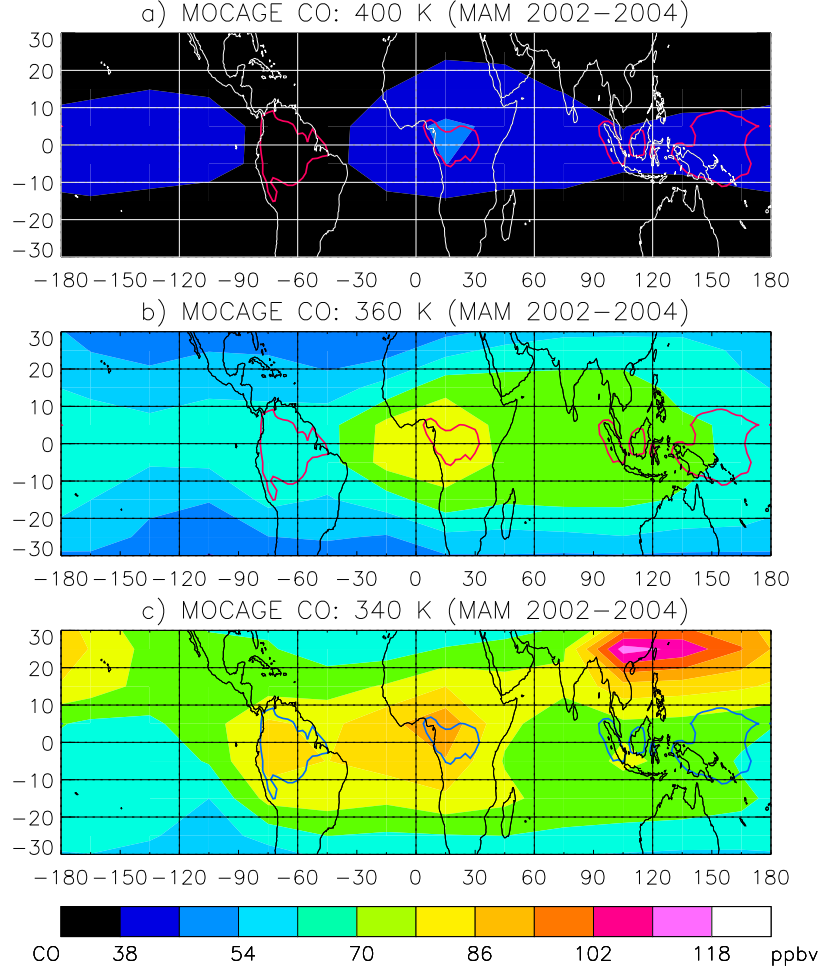

Fig. 11. Same as Fig. 9 but for CO.

sign of increase over South-America. Another different feature is the extension of the maximum amount in the model towards tropical latitudes, particularly over South-East Asia in the upper troposphere. At $400 \mathrm{~K}$ in the lower stratosphere, there is still some indication of a maximum over Africa, but the amplitude of the longitudinal peak-to-trough value (1$2 \mathrm{ppbv})$ is significantly weaker than that of SMR (11 ppbv) and even MLS (5 ppbv). The $\mathrm{CH}_{4}$ MOCAGE fields are similar to those of $\mathrm{N}_{2} \mathrm{O}$ showing even more developed extension of the African maximum towards Asia, which could be seen also in HALOE, although less pronounced. But again, as for $\mathrm{N}_{2} \mathrm{O}$, the amplitude of the longitudinal modulation of $\mathrm{CH}_{4}$ at $400 \mathrm{~K}$ in the stratosphere vanishes in the model $(0.02 \mathrm{ppmv})$ compared to the $0.13 \mathrm{ppmv}$ of the observations. Finally, the MOCAGE CO simulations at $340 \mathrm{~K}$ (Fig. 11) are more consistent with MOPITT at $150 \mathrm{hPa}$ than with MLS observations at $150 \mathrm{hPa}$. Although maxima are present over Africa and South America in the three data sets, only MOPITT and MOCAGE display a maximum $\mathrm{CO}$ over South-East Asia. Again note that the MOPITT 150-hPa averaging kernels cover a broad layer in the mid-to-upper troposphere whilst MLS 150-hPa averaging kernels are peaking around $150 \mathrm{hPa}$. The Asian maximum remains tropospheric in the model, not propagating at $360 \mathrm{~K}$ and $400 \mathrm{~K}$. Finally, the model longitudinal peak-to-trough values are about $20 \mathrm{ppbv}$ at $360 \mathrm{~K}$ and $\sim 10 \mathrm{ppbv}$ at $400 \mathrm{~K}$, i.e. close or slightly smaller than MLS values ( $\sim 40 \mathrm{ppbv}$ at $360 \mathrm{~K}$ and $\sim 10 \mathrm{ppbv}$ at $400 \mathrm{~K})$.
In conclusion, MOCAGE always shows a $\mathrm{N}_{2} \mathrm{O}, \mathrm{CH}_{4}$ and $\mathrm{CO}$ maximum concentration over Africa in the troposphere at $340 \mathrm{~K}$ extending to the tropopause. But what is missing in the model compared to observations, are the $\mathrm{N}_{2} \mathrm{O}$ and $\mathrm{CH}_{4}$ secondary maxima over South America and Indonesia. Another difference is the stronger concentration in the model of the three species in the upper troposphere over Asia and the North-West Pacific. But most noticeable regarding the impact of convection is the very small amplitude of the longitudinal change of $\mathrm{N}_{2} \mathrm{O}$ and $\mathrm{CH}_{4}$ concentrations in the lower stratosphere compared to observations, suggesting that the model does not capture properly the tropospherestratosphere transport.

\subsection{Discussion}

Several reasons can be invoked which could potentially explain at least part of the differences between the model and observations. Most obvious are the distribution and intensity of the sources and the horizontal transport at the surface, the representation of convection and ultimately of mass flux across the tropopause. The sensitivity of the species distribution at the tropopause to those parameters is explored below.

\subsubsection{Source distribution and horizontal transport at the} surface

The horizontal distribution of a trace gas lifted in the upper troposphere depends on the location of convective systems but also on the distribution of the gas at surface levels, that is, on the location and intensity of their sources and on horizontal transport near the surface and finally on the life time of the species. The concentration of a long-lived species such as $\mathrm{N}_{2} \mathrm{O}$ of 130-140 year lifetime should be more homogeneous than that of $\mathrm{CH}_{4}$ of 8-10 year lifetime, or $\mathrm{CO}$ of 2-month lifetime only. For better testing the impact of the inhomogeneity of surface emission on the distribution for the species in the TTL, we have also considered CFC11, a long-lived species ( $\sim 50 \pm 5$ year lifetime) emitted only in the Northern Hemisphere industrialized countries, and $\mathrm{CH}_{3} \mathrm{Cl}$, a shorterlived species ( $\sim 1.5$ year lifetime) of both land and oceanic origin, whose distribution in MOCAGE is relaxed between $550 \mathrm{hPa}$ and the surface towards a globally-averaged value specified in WMO (2002), with a relaxation time of 7 days.

As an example of the highly contrasted source distribution, Fig. 12 shows the surface emissions of $\mathrm{N}_{2} \mathrm{O}, \mathrm{CH}_{4}, \mathrm{CO}$ and CFC11 in April 2003 used in MOCAGE (Sect. 3.1). Though oceanic emissions slightly contribute, the main sources of $\mathrm{N}_{2} \mathrm{O}$ are the regions of dense vegetation, Amazonia and the Congo basin in the tropics and South-East Asia. In the inventory, the sources of $\mathrm{CH}_{4}$ are mainly wetlands in SouthEast Asia, and for a smaller part biomass burning, which explains the emissions in Africa and South America correlated with TRMM/VIRS fire counts during the same season. Note that equatorial primary forests are not sources 
$\mathrm{N}_{2} \mathrm{O}$ EMISSIONS

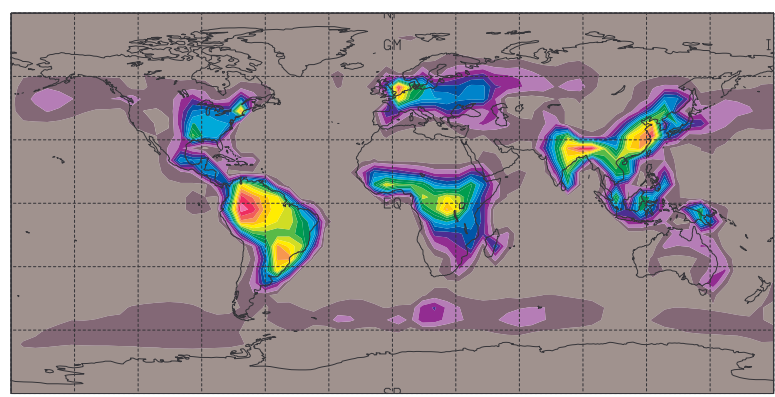

$\times 10^{-12} \mathrm{~mole} / \mathrm{s}$

CO EMISSIONS

CO EMISSIONS

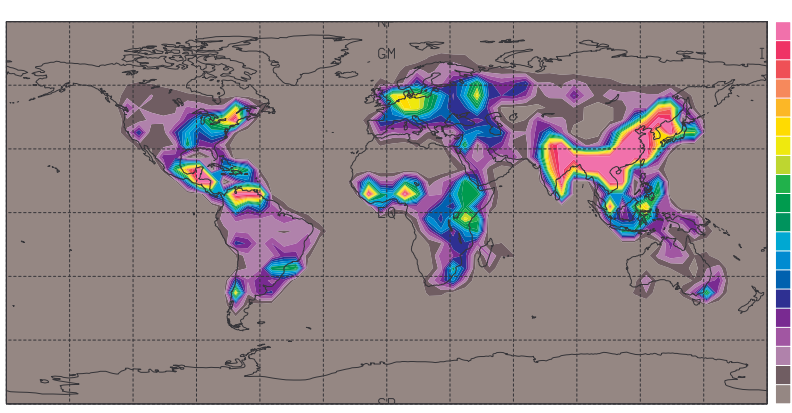

$\times 10^{-09} \mathrm{~mole} / \mathrm{s}$
$\mathrm{CH}_{4}$ EMISSIONS

APRIL 2003

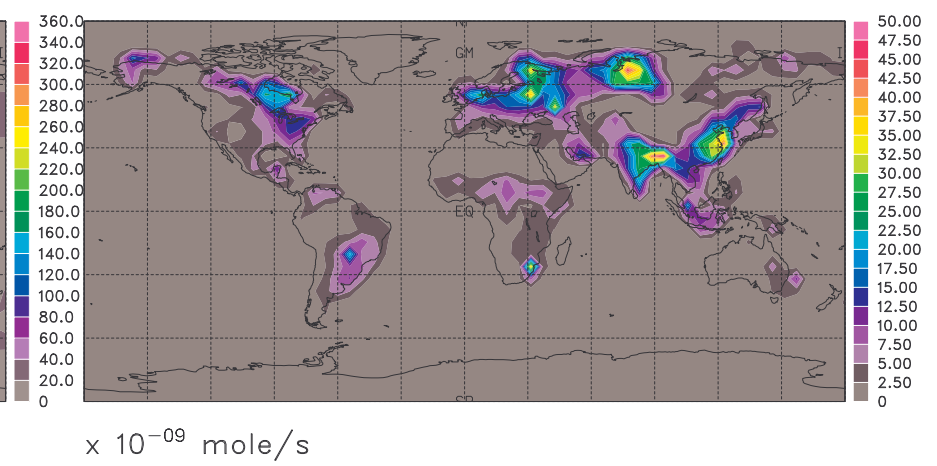

CFC-11 EMISSIONS

APRIL 2003

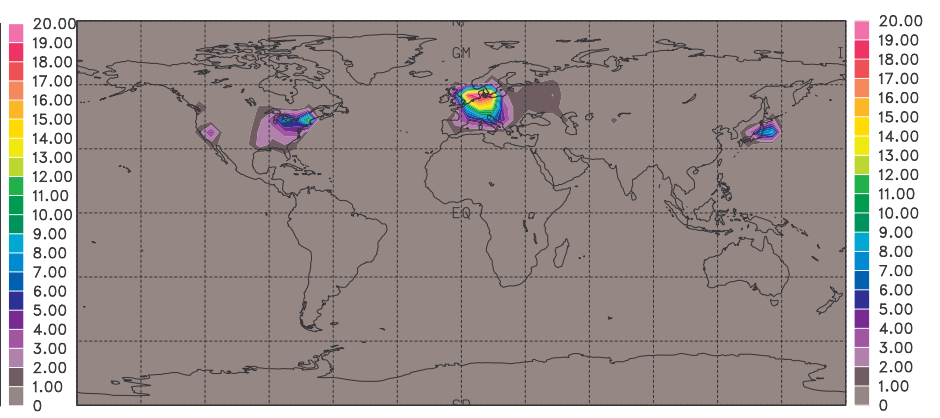

$\times 10^{-12} \mathrm{~mole} / \mathrm{s}$

Fig. 12. Trace gas emission in April 2003 at the surface used in MOCAGE. Upper left: $\mathrm{N}_{2} \mathrm{O}$ in $10^{-12}$ mole s${ }^{-1}$; Upper right: $\mathrm{CH}_{4}$ in $10^{-8}$ mole s $^{-1}$; Bottom left: CO in $10^{-9}$ mole s $^{-1}$; Bottom right: CFC11 in $10^{-9}$ mole s $^{-1}$.

of $\mathrm{CH}_{4}$ in this inventory. This is in contradiction with recent ENVISAT/SCIAMACHY observations indicating significant emissions from evergreen forests in South America (Frankenberg et al., 2006) which may indicate a systematic underestimation of $\mathrm{CH}_{4}$ also in Africa and the Indonesian Islands. $\mathrm{CO}$ emissions in the tropics are mainly related to biomass burning, though the largest source is pollution in populated and industrial areas. Most intense $\mathrm{CO}$ emissions in the inventory are those located over India, South-East Asia and China, although it must be remembered that their intensity could be highly variable from one year to another. Finally and although not measured, Fig. 12 shows the sources of CFC11.

Apart from sources location and intensity, the distribution of trace gases at the surface is also controlled by horizontal transport. Figure 13 shows the average ECMWF mean wind field at 1-km height during the MAM season in 20022004. Equatorial convective areas are also regions of convergence of North-East and South-East oceanic trade winds on both sides of the ITCZ. However, Equatorial Africa and to a lesser degree the North-West part of South America are different, where advected air masses are passing over continental surfaces instead of oceans and therefore enriched in continental gases compared to oceanic air masses. The in- fluence of horizontal transport can be seen in the MOPITT $\mathrm{CO}$ at $850 \mathrm{hPa}$, displaying a large mixing ratio on the west side of Africa and South America extending to the adjacent ocean, in contrast to the east side of the continents where the $\mathrm{CO}$ concentration is close to that over ocean, features well captured by MOCAGE. Asides from being a source region itself, Equatorial Africa appears as a region of accumulation and thus of highest land trace gases concentration compared to other tropical continents.

Figures 14 and 15 show the distributions of CFC11 and $\mathrm{CH}_{3} \mathrm{Cl}$ as calculated by MOCAGE, respectively at $400 \mathrm{~K}$, $360 \mathrm{~K}$ and $340 \mathrm{~K}$ in MAM 2002-2004. Although emitted in the northern mid-latitude only, the simulated CFC11 distribution at $400 \mathrm{~K}$ is very similar to that of $\mathrm{N}_{2} \mathrm{O}$ (Fig. 9a). Furthermore, it shows a maximum over Africa at $340 \mathrm{~K}$ and $360 \mathrm{~K}$, similar to that of $\mathrm{N}_{2} \mathrm{O}$, although there is no emission there, demonstrating the importance of convergence of surface emitted species over that continent. The same could be deduced from $\mathrm{CH}_{3} \mathrm{Cl}$ showing higher concentration at $340 \mathrm{~K}$ around $15^{\circ} \mathrm{S}$ above the convergence zones of the Southern Hemisphere, drifting to $5^{\circ} \mathrm{S}$ at $360 \mathrm{~K}$. But in that case, and in contrast to all other species, a relative maximum is present over the Western Pacific. However, the difference vanishes at $400 \mathrm{~K}$, where the figure is the same as for all others display- 


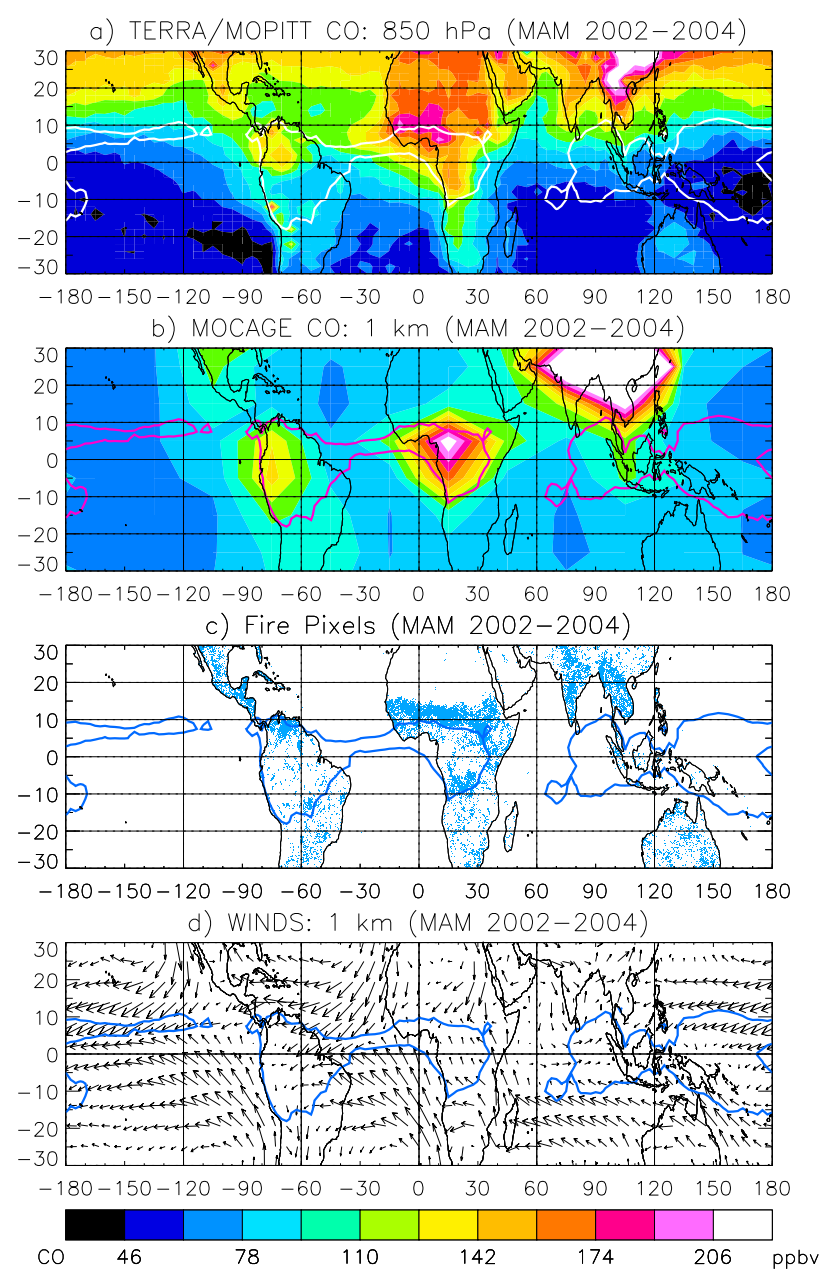

Fig. 13. From top to bottom: CO MOPITT at $850 \mathrm{hPa}, \mathrm{CO}$ MOCAGE at $1 \mathrm{~km}$, TRMM/VIRS fire counts, and ECMWF horizontal wind at $1 \mathrm{~km}$ height, all averages during MAM 2002-2004. White, red or blue isolines are representing $236 \mathrm{Wm}^{-2}$ OLR.

ing a zonal band with two weak maximum areas over Africa and the mid-Pacific but of very limited longitudinal contrast of $\pm 1 \mathrm{ppbv}$. At this altitude level, the location of the source has no more impact on MOCAGE.

In conclusion, although of different sources distributed differently and of different lifetimes, the tropospheric-origin trace gas distributions are very similar when reaching the tropopause level displaying all a relatively enriched area over the African sector, extending to South-East Asia for $\mathrm{CH}_{4}$ and $\mathrm{CO}$ having intense sources there, and to the Western Pacific for $\mathrm{CH}_{3} \mathrm{Cl}$ largely of oceanic origin. Although the source location and intensity play a role, the model study suggests that the main driver for the maximum mixing ratios over convective areas at equator is the associated convergence at surface levels.

However, from MOCAGE, the influence of sources and horizontal redistribution reduces rapidly at upper levels at

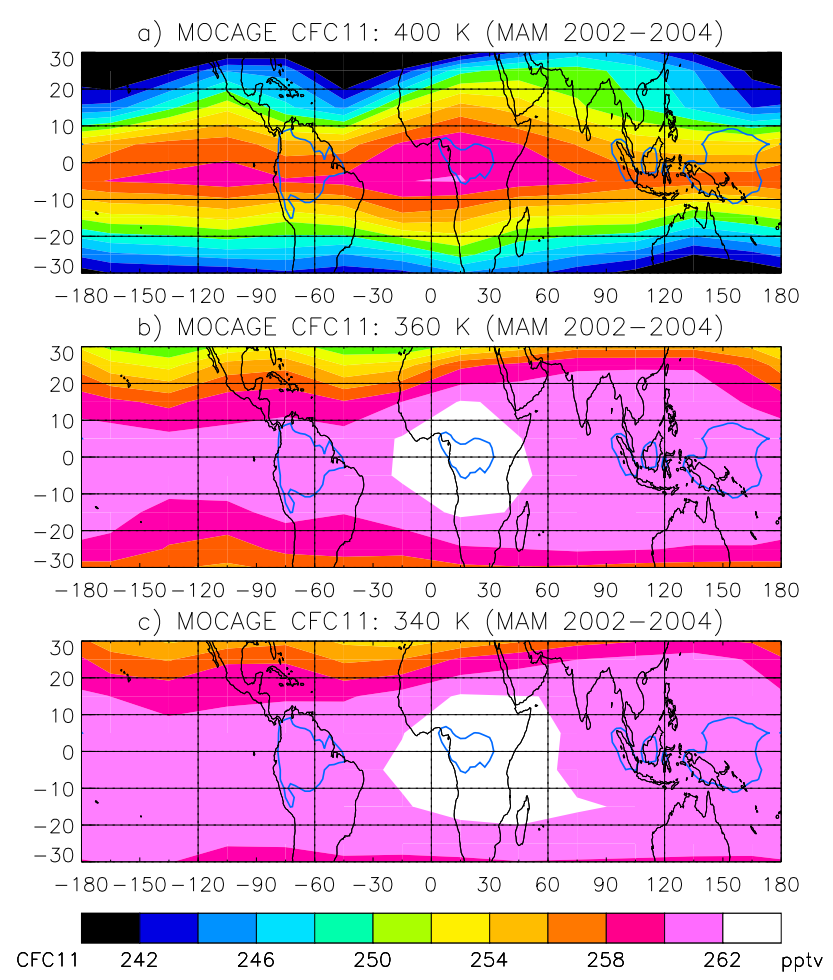

Fig. 14. MOCAGE CFC11 in MAM 2002-2004 at (a) 400, (b) 360 and (c) $340 \mathrm{~K}$.

$400 \mathrm{~K}$ in the lower stratosphere, where all species are showing almost the same feature: an equatorial belt with two maximum areas over Africa and the East Pacific, but of very little longitudinal contrast. At these levels, the distribution of the species is largely the result of the uplift by the residual circulation of the meteorological analyses.

\subsubsection{Representation of convection in the model}

The top height, frequency and diurnal cycle of convection simulated by MOCAGE have been studied by calculating probability density function (PDF) of the top of convective events, defined as the highest model layer reached by convective clouds. The results for three convective regions between $10^{\circ} \mathrm{S}-10^{\circ} \mathrm{N}$, Western Pacific $\left(135^{\circ} \mathrm{E}-165^{\circ} \mathrm{E}\right)$, South America $\left(45^{\circ} \mathrm{W}-75^{\circ} \mathrm{W}\right)$, and Africa $\left(15^{\circ} \mathrm{E}-45^{\circ} \mathrm{E}\right)$ are shown in Fig. 16. Convection frequently reaches $100-300 \mathrm{hPa}(82 \%$, $76 \%$ and $65 \%$ at the 3 locations, respectively), less frequently $150 \mathrm{hPa}(26 \%, 20 \%$ and $12 \%$, respectively), on rare occasions (a few \%) $125 \mathrm{hPa}$, and never above. Besides the slightly smaller daily average frequency, the main difference between continental and oceanic convection resides in the diurnal cycle. A maximum development is observed around 13:00-15:00 hour (local time) over Africa and South America afterwards the altitude of cloud top drops in the afternoon and in the evening. In contrast, the Western Pacific shows a weak diurnal cycle with a maximum height of convection 


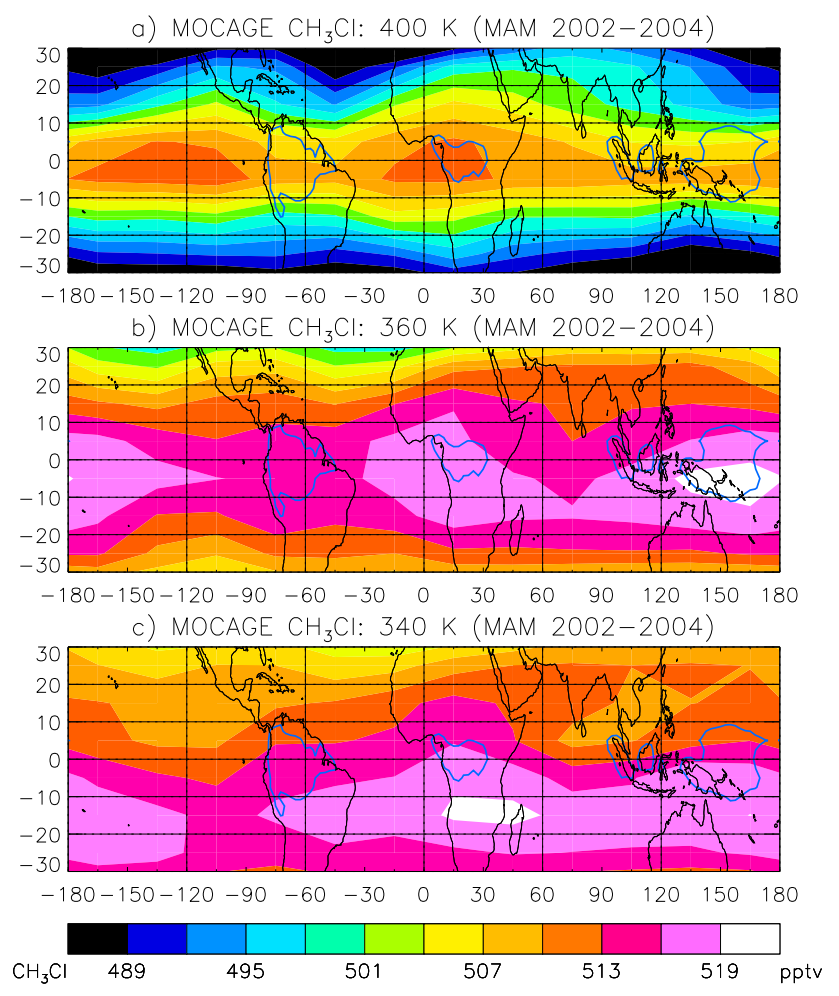

Fig. 15. Same as Fig. 14 but for $\mathrm{CH}_{3} \mathrm{Cl}$.

around 06:00-09:00 hour (local time). At the local time of maximum development, the frequency of convective systems reaching $300-150 \mathrm{hPa}$ increases to $92 \%$ over the Western Pacific and $82 \%$ over both continents.

In summary, the altitude reached by convective systems simulated in MOCAGE is roughly the same over the Pacific than over Equatorial Africa and South America, although the frequency of occurrence is slightly larger in the first case. The MAM distribution of OPFs from the TRMM radar (see Fig. 2 in Liu and Zipser, 2005) is given as a normalized density distribution of overshoots above $14 \mathrm{~km}$ within cells of $5^{\circ} \times 5^{\circ}$ from $20^{\circ} \mathrm{S}$ to $20^{\circ} \mathrm{N}$. Consequently, TRMM OPFs are qualitatively comparable and are consistent with MOCAGE PDFs. The main difference between continental and oceanic convection is the presence of a strong diurnal cycle over land with a maximum development peaking in the early afternoon, in opposition to a change of smaller amplitude peaking in the early morning over ocean. However, it must be emphasised that due to its relatively broad horizontal resolution $\left(5.8^{\circ} \times 5.8^{\circ}\right)$, MOCAGE can hardly capture the local vertical transport associated with mesoscale convective systems, as well as small scale local overshooting in the stratosphere associated to land thunderstorms.
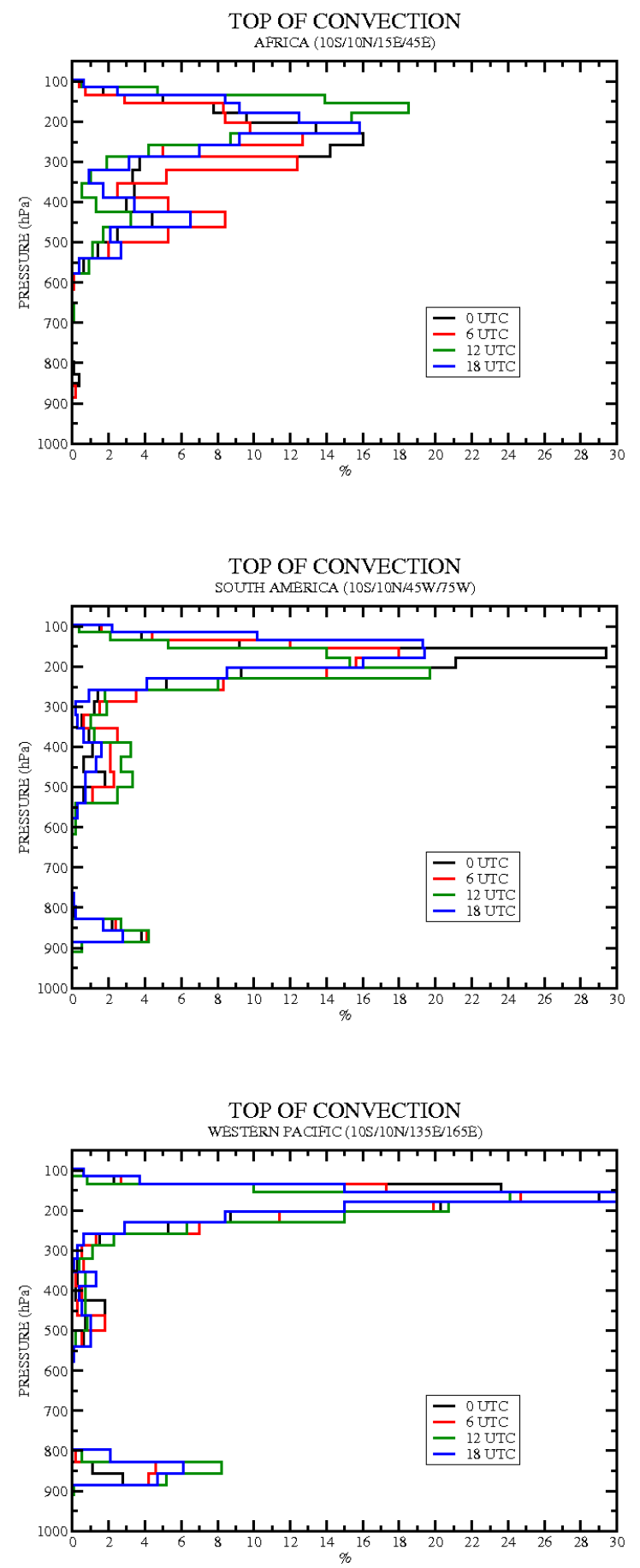

Fig. 16. Probability Density Function of altitude reached by convection in MOCAGE in MAM 2002-2004 within a $10^{\circ} \mathrm{S}-10^{\circ} \mathrm{N}$ latitude band at 00:00, 06:00, 12:00 and 18:00 UTC, over Africa (top), South America (middle) and Western Pacific (bottom). The vertical grid is representative of each vertical layer in MOCAGE. 


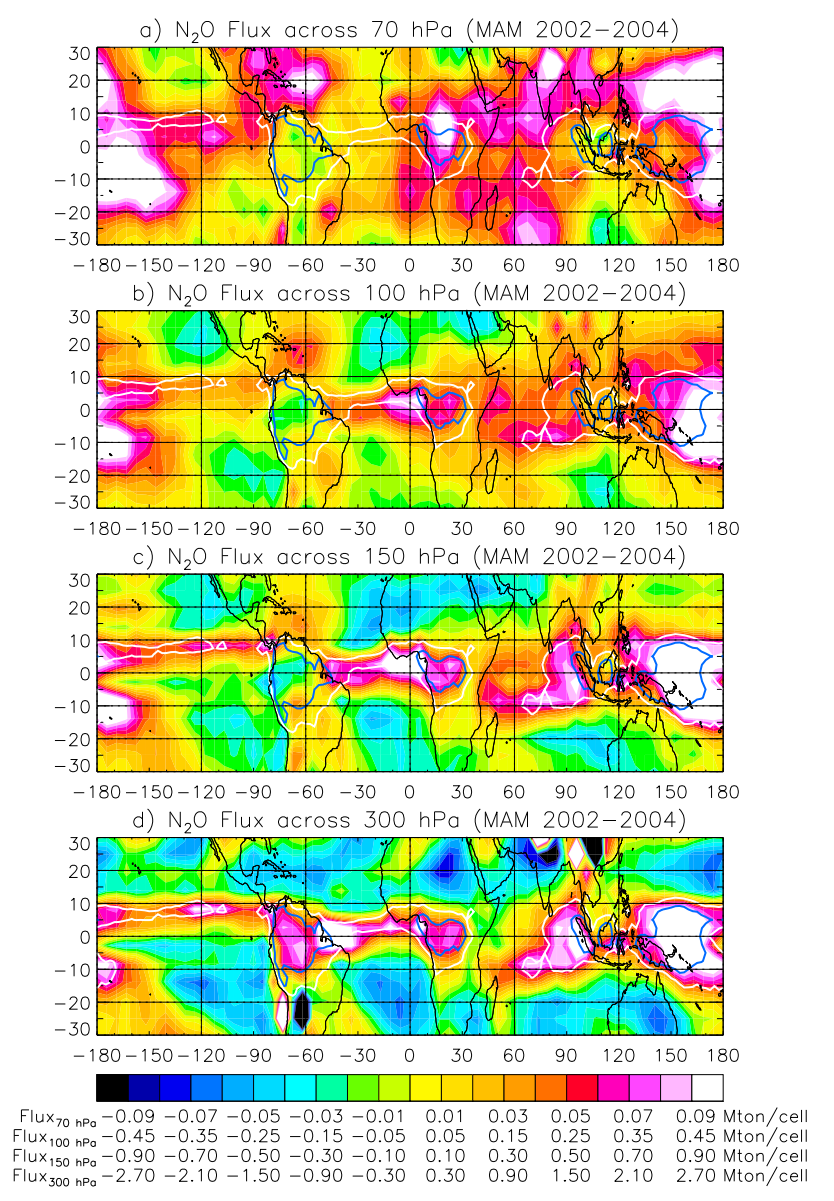

Fig. 17. MOCAGE $\mathrm{N}_{2} \mathrm{O}$ vertical flux across (a) 70, (b) 100 , (c) 150 and (d) $300 \mathrm{hPa}$. Note the progressive increase of colour scale at increasing altitude.

\subsubsection{Representation of $\mathrm{N}_{2} \mathrm{O}$ mass flux in the TTL}

An indicator of the contribution of convection and residual vertical transport provided by ECMWF is the mass flux of a species at different levels. Figure 17 shows the $\mathrm{N}_{2} \mathrm{O}$ vertical flux at $70 \mathrm{hPa}, 100 \mathrm{hPa}, 150 \mathrm{hPa}$, and $300 \mathrm{hPa}$, expressed in Mton/cell of MOCAGE $\left(5.8^{\circ} \times 5.8^{\circ}\right)$, where positive (negative) values mean upward (downward) fluxes. At $300 \mathrm{hPa}$, areas of upward vertical transport match the location of intense convective systems and the ITCZ, and large areas of subsidence are observed elsewhere. The largest upward transport is located over the Western Pacific. The picture is very similar at $150 \mathrm{hPa}$ although the flux drops by a factor 3 , with the remarkable exception of South America, where it becomes negative over Amazonia. At $100 \mathrm{hPa}$, the flux drops again by a factor 2 , though there is still some correlation between upward flux and convection. Note that the maximum upward flux is starting being displaced from the Western Pacific to the Central Pacific following the ITCZ. Finally, at $70 \mathrm{hPa}$ in the lower stratosphere, the flux dramatically reduces by
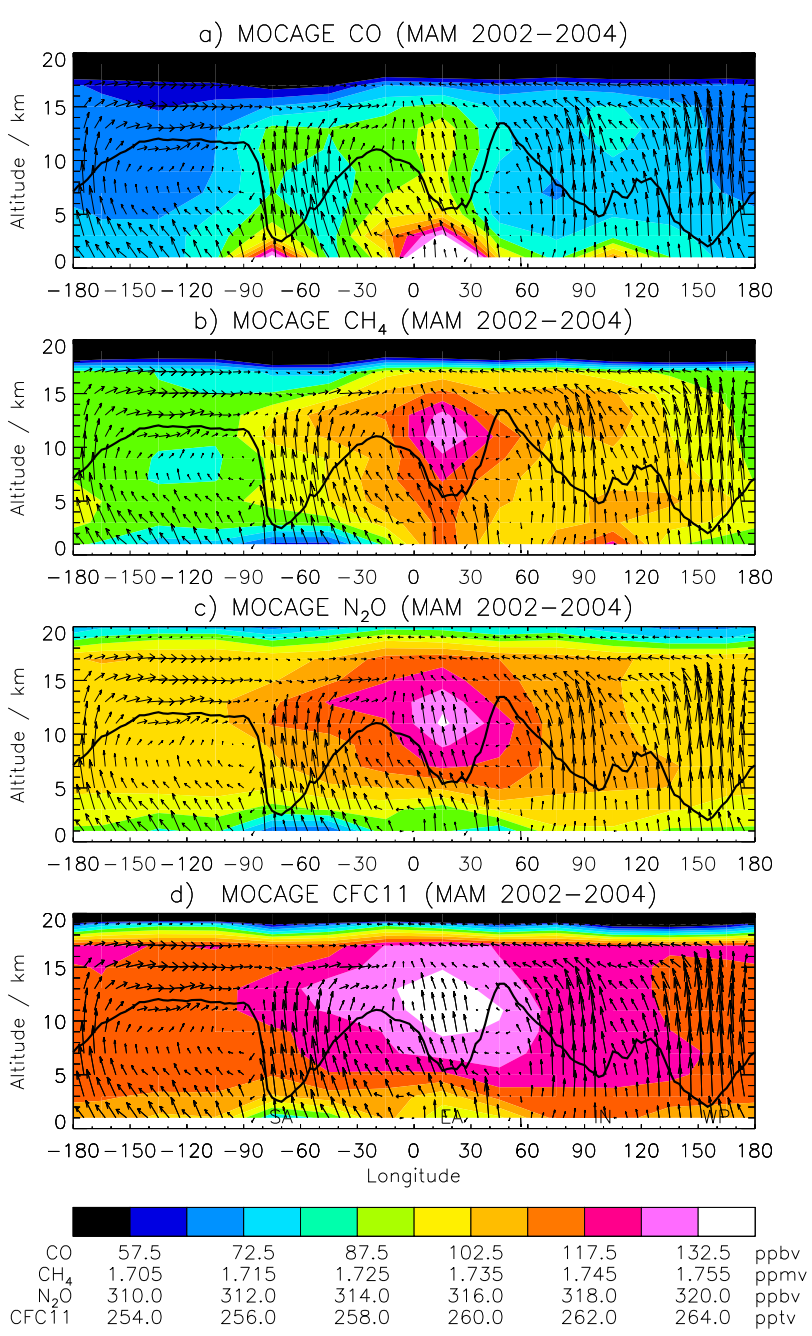

Fig. 18. Altitude-longitude cross-section of trace gas mixing ratio in the $10^{\circ} \mathrm{S}-10^{\circ} \mathrm{N}$ equatorial band calculated by MOCAGE for MAM 2002-2004. From top to bottom: $\mathrm{CO}, \mathrm{CH}_{4}, \mathrm{~N}_{2} \mathrm{O}$ and CFC11. Arrows are showing the wind direction and speed where the vertical component is amplified by a factor 100 . Also shown by a bold line is the zonal variation of OLR.

a factor 5 compared to $100 \mathrm{hPa}$ and becomes positive on average over the whole $\pm 30^{\circ}$ tropical band, not showing any more correlation with convective regions. Convective transport stops at $100 \mathrm{hPa}$ in MOCAGE.

\subsubsection{Longitudinal distribution of the species in the equa- torial troposphere}

The most intriguing feature in the MOCAGE simulations is that despite of the fact that the most intense upward flux is located over the Western Pacific in the troposphere, all species always show a maximum concentration at the tropopause over Africa, and South-East Asia for those of more intense emission there, suggesting a strong influence of horizon- 
tal transport within the troposphere. Figure 18 displays an altitude-longitude cross-section of the average model concentration of $\mathrm{CO}, \mathrm{CH}_{4}, \mathrm{~N}_{2} \mathrm{O}$ and $\mathrm{CFC} 11$ in MAM 20022004 together with zonal/vertical winds shown by arrows, where the vertical component is amplified by a factor 100 . Also plotted is the zonal variation of AVHRR OLR showing deepest minima over the Western Pacific and South America, and two others of a little less amplitude over Africa and Indonesia.

At surface level, as discussed in Sect. 3.3.1, the model CO concentration is the largest over Africa and then South America and Indonesia. The signature of a fast convective transport between the surface and the UT could be seen over the three areas, resulting in peak mixing ratios at $12-13 \mathrm{~km}$ more pronounced over Africa. Then, the CO concentration drops sharply around $17 \mathrm{~km}$. As already seen in the previous section, the upward transport stops over South America at about $13 \mathrm{~km}$. The larger CO in the UT over Africa is clearly related to the larger surface concentration.

The modelled $\mathrm{CH}_{4}$ concentration at the surface is the largest over Africa and then South-East Asia but, as already discussed, smaller over South America. As for CO, fast convection results in a maximum around $12-13 \mathrm{~km}$, but of larger amplitude than at the surface, suggesting some enrichment by horizontal advection from other longitudes. Note that, in the mid-to-upper troposphere, meridional winds diverge from the Equator to the tropics (Hadley cells). Furthermore, there is no indication of significant $\mathrm{CH}_{4}$ penetration in the $\mathrm{LS}$ above $17 \mathrm{~km}$. As for $\mathrm{CO}$, the $\mathrm{CH}_{4}$ African maximum in the UT is clearly related to its higher concentration at the surface, but requires also some enrichment by advection from other longitudes. The longer lifetime of the $\mathrm{N}_{2} \mathrm{O}$ species makes its concentration more homogeneous in the UT and of weaker gradient at the tropopause. A maximum in model concentration is observed in the UT over Africa but not directly related with an increase at the surface. Africa is not an area of high $\mathrm{N}_{2} \mathrm{O}$ surface concentration. An advection from other longitudes is required. Finally, a maximum in modelled CFC11 is also present in the UT over Africa, although the sources of CFC11 are all located at northern mid-latitudes. As for $\mathrm{N}_{2} \mathrm{O}$, this implies horizontal advection in the mid-troposphere before convective uplift.

The slightly depleted amounts of surface $\mathrm{N}_{2} \mathrm{O}$ in the model and, to a lesser extent, of surface $\mathrm{CH}_{4}$ and $\mathrm{CFC} 11$ over South America and Africa compared to the maximum $\mathrm{CO}$, can be explained by respective relative intensity of their sources $\left(\sim 100\right.$ molecules $\mathrm{m}^{-2} \mathrm{~s}^{-1}$ for $\mathrm{CO}, \sim 1-$ 10 molecules $\mathrm{m}^{-2} \mathrm{~s}^{-1}$ for $\mathrm{CH}_{4},<1$ molecule $\mathrm{m}^{-2} \mathrm{~s}^{-1}$ for $\mathrm{N}_{2} \mathrm{O}$ ), compared to the convergence of oceanic air of poorer concentration at the base of convective systems. As shown by the wind vectors in Fig. 18, the enrichment of concentration between $10-14 \mathrm{~km}(300-150 \mathrm{hPa})$ over Africa and more generally the Western hemisphere between $90^{\circ} \mathrm{W}-120^{\circ} \mathrm{E}$, is largely resulting from a convergence in the upper troposphere compared to the divergent Pacific area.

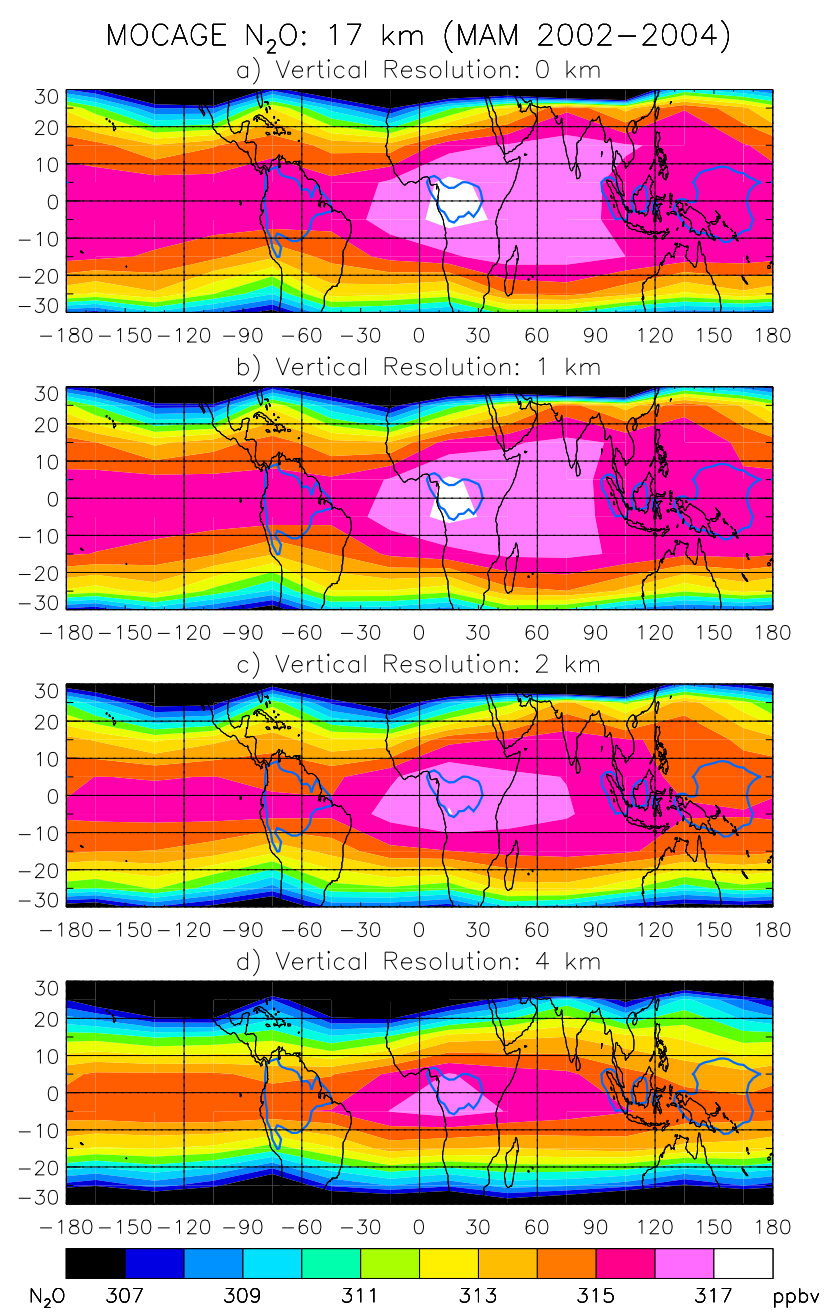

Fig. 19. Theoretical impact of the vertical resolution on the $\mathrm{N}_{2} \mathrm{O}$ distribution at $17 \mathrm{~km}$. From top to bottom: MOCAGE simulation at $17 \mathrm{~km}$, and degraded simulation at a resolution of 1,2 and $4 \mathrm{~km}$.

\section{Discussion}

As shown in the previous section, the maximum concentration of the tropospheric gas-trace species at the tropopause over the Western Hemisphere and particularly Africa is largely the result of convective and large-scale horizontal transport from source regions in the troposphere. The location of the sources appears relatively less important although it has an influence in case of very intense emissions such as $\mathrm{CO}$ and, to a lesser extent, $\mathrm{CH}_{4}$ in South-East Asia. The MOCAGE simulations capture quite well the observed distribution of the species, but largely underestimate the amplitude of the contrast between areas of maximum and minimum concentration at the tropopause and even more in the stratosphere where large differences could be found with the observations. Two possible reasons may be invoked for explaining such large differences: i) the broad vertical resolution of space-borne observations compared to the model, and 


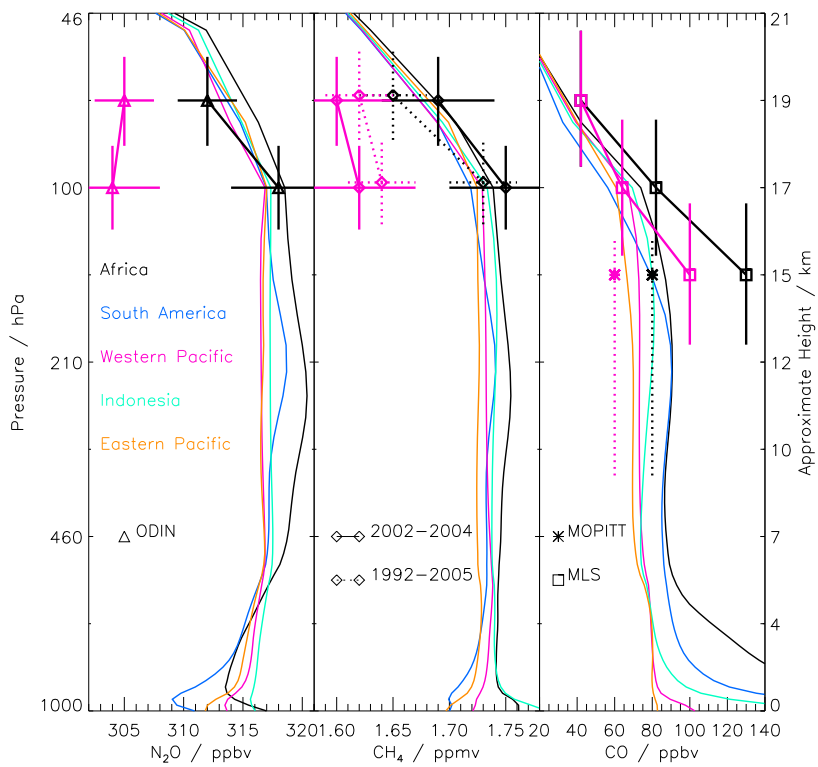

Fig. 20. $\mathrm{N}_{2} \mathrm{O}, \mathrm{CH}_{4}$ and $\mathrm{CO}$ vertical profiles simulated by MOCAGE (solid lines), and observed by SMR (triangle), HALOE (diamond) and MOPITT (star). Black: Africa. Blue: South America. Red: Western Pacific. Green: Indonesia. Orange: Eastern Pacific. The vertical bars represent the vertical resolution of the satellite measurements whilst the horizontal bars indicate the average random error associated with satellite observations.

ii) the representation of the vertical transport in the TTL and the lower stratosphere in the model.

4.1 Impact of broad vertical resolution of satellite observations

The vertical resolution of the limb-viewing $\mathrm{CO}, \mathrm{CH}_{4}$ and $\mathrm{N}_{2} \mathrm{O}$ instruments in the UTLS is ranging from 2 to $4 \mathrm{~km}$ while it is about $6-8 \mathrm{~km}$ for the CO nadir-viewing MOPITT providing independent information into two layers only in the troposphere. Figure 19 displays the theoretical impact of the vertical resolution on the $\mathrm{N}_{2} \mathrm{O}$ field at $17 \mathrm{~km}$ provided by MOCAGE, and by convolution of the MOCAGE profiles with a triangular filter of 1-km, 2-km (similar to ODIN) and 4-km (similar to MLS) full-width at half-maximum. The degradation of resolution results in: i) a sharper meridional gradient consistent with observations (Figs. 3 and 4), and ii) the lessening of the average value and the smoothing of the longitudinal contrast between maximum and minimum concentrations, but no change in their location.

\subsection{Vertical transport}

The MOCAGE $\mathrm{N}_{2} \mathrm{O}, \mathrm{CH}_{4}$ and $\mathrm{CO}$ profiles over Africa, South America, Indonesia and Western Pacific are shown in Fig. 20 together with the observations of the space-borne instruments over Africa in black and the Pacific in red. Be- cause of their inconsistent high and low biases at $100 \mathrm{hPa}$ and $70 \mathrm{hPa}$ (see Sect. 2.3), the currently available MLS version $1.5 \mathrm{~N}_{2} \mathrm{O}$ retrievals are ignored in this representation of vertical gradients.

Although observed and modelled concentrations at the tropopause are very consistent over Africa, the most remarkable feature shown in the figure is the large overestimation of $\mathrm{N}_{2} \mathrm{O}$ and $\mathrm{CH}_{4}$ over the Pacific at and above the tropopause and, surprisingly, of the vertical gradient of the species in the stratosphere, weaker in the model even over the most convective area in Africa. Moreover, although the HALOE $\mathrm{CH}_{4}$ average concentration in MAM over Central America is consistent with the WB57F measurements in January 2004 over Costa-Rica (Richard et al., 2006) both showing reduced concentration at $100 \mathrm{hPa}$ compared to the tropospheric value (not shown), there is no indication in the model of fall-off above $14 \mathrm{~km}$ in the UT, at any longitude, such as that reported by the aircraft.

In contradiction to observations, the vertical transport in the UTLS in the model does not vary in longitude and in addition is too strong on average. This is consistent with the known overestimation of the vertical wind above the zero net radiative heating level at $14 \mathrm{~km}$ derived from the residual circulation in meteorological models (Waugh and Hall, 2002) and in MOCAGE in particular (Teyssèdre et al., 2007), implying an overestimation of the average mass flux at the tropopause in the tropics.

The observed large longitudinal variation of concentration at both 17 and $19 \mathrm{~km}$ would imply a vertical transport of the same amplitude as in the model, but limited to convective regions. The proposal for this localised additional transport is the fast convective overshoot of tropospheric air in the lower stratosphere as observed in February 2004 over Brazil (Pommereau and Held, 2007), successfully captured by high spatial resolution Cloud Resolving Models (Chaboureau et al., 2007; Grovesnor et al., 2007). The stronger uplift over Africa in MAM very consistent with the maximum TRMM radar OPFs over the same region at the same season strongly supports the suggestion.

\section{Concluding remarks}

The average horizontal distributions of $\mathrm{N}_{2} \mathrm{O}, \mathrm{CH}_{4}$ and $\mathrm{CO}$ in the tropical UTLS as reported by space-borne instruments during the March-April-May season do show significant longitudinal gradients with maximum amounts over land convective areas, primarily Africa and, depending on the species, above northern South America and South-East Asia although less pronounced. The lower stratosphere over the Western Pacific convective region where the outgoing longwave radiation is the lowest, the tropopause the highest and the coldest, appears as a region of minimum concentration of tropospheric-origin trace species. 
The possible impact on trace gas concentration at the tropopause of the inhomogeneous distribution and intensity of the sources, mostly continental, and of the horizontal transport in the troposphere, were explored with the MOCAGE Chemistry Transport Model. Significant impact (30\% variation) was found on the concentration in the upper troposphere for the medium-lived CO (2-month lifetime), whose concentration is in addition underestimated by the model in the upper troposphere, but very limited (no more than $1 \%$ ) on $\mathrm{CH}_{4}$ (8-10 year lifetime) and $\mathrm{N}_{2} \mathrm{O}$ (130 yearlifetime).

The large contrast of $\mathrm{N}_{2} \mathrm{O}$ and $\mathrm{CH}_{4}$ concentrations between convective and non-convective areas reported by the space-borne instruments at the tropopause and in the lower stratosphere not captured by the model, requires thus another explanation. The suggestion is of strong overshooting over land convective regions, particularly Africa, very consistent with the maximum TRMM radar overshooting features over the same region during the same season. Compared to observations, the MOCAGE model forced by ECMWF analyses is found to ignore these fast-localised uplifts, but to overestimate the uniform vertical transport in the UTLS at all longitudes in the tropics.

Acknowledgements. We would like to thank our colleagues from the ODIN and the NCAR MOPITT teams, and M. Michou at CNRM (France) for helpful comments on MOCAGE-Climat. ODIN is a Swedish-led satellite project funded jointly by the Swedish National Space Board (SNSB), the Canadian Space Agency (CSA), the National Technology Agency of Finland (Tekes), and the Centre National d'Etudes Spatiales (CNES). ODIN data V222 are stored in the ETHER French atmospheric data base (http://ether.ipsl.jussieu.fr). Aspects of the research described in this paper carried out by the Jet Propulsion Laboratory, California Institute of Technology, was under a contract with the National Aeronautics and Space Administration. This project was supported by the European Commission within the HIBISCUS programme (contract EVK2-2001-000111) and by the Programme National de Chimie Atmosphérique (PNCA) in France. B. Barret has been funded by the European Integrated Project SCOUT-O3. Interpolated OLR data are provided by the NOAA-CIRES ESRL/PSD Climate Diagnostics branch, Boulder, Colorado, USA, from their Web site at http://www.cdc.noaa.gov/. The TRMM/VIRS data used in this study were acquired as part of the NASA's Earth-Sun System Division and archived and distributed by the Goddard Earth Sciences (GES) Data and Information Services Centre (DISC) Distributed Active Archive Centre (DAAC). We finally would like to thank all the reviewers and the editor for their very fruitful comments.

Edited by: R. MacKenzie

\section{References}

Alcala, C. M. and Dessler, A. E.: Observations of deep convection in the tropics using the TRMM precipitation radar, J. Geophys. Res., 107(D24), 4792, doi:10.129/2002JD002457, 2002.

Barret, B., De Mazière, M., and Mahieu, E.: Ground-based FTIR measurements of $\mathrm{CO}$ from the Jungfraujoch: characterisation and comparison with in situ surface and MOPITT data, Atmos. Chem. Phys., 3, 2217-2223, 2003,

http://www.atmos-chem-phys.net/3/2217/2003/.

Barret, B., Ricaud, P., Santee, M. L., et al.: Intercomparisons of trace gases profiles from the Odin/SMR and Aura/MLS limb sounders, J. Geophys. Res., 111, D21302, doi:10.1029/2006JD007305, 2006.

Betchold, P., Bazile, E., Guichard, F., Mascart, P., and Richard, E.: A mass flux convection scheme for regional and global models, Q. J. Roy. Meteor. Soc., 127, 869-886, 2001.

Bouwman, A. F., Van der Hoek, K. W., and Olivier, J. G. J.: Uncertainties in the global source distribution of nitrous oxide, J. Geophys. Res., 100(D2), 2785-2800, 1995.

Brasseur, G. P., Orlando, J. J., and Tyndall, G. S.: Atmospheric chemistry and global change, 2nd edition, Oxford University Press, New York, Oxford, ISBN-0-19-510521-4, 1999.

Chaboureau, J.-P., Cammas, J.-P., Duron, J., Mascart, P. J., Sitnikov, N. M., and Voessing, H.-J.: A numerical study of crosstropopause transport by convective overshoots during the Troccinox golden day, Atmos. Chem. Phys., 7, 1731-1740, 2007, http://www.atmos-chem-phys.net/7/1731/2007/.

Christian, H. J., Blakeslee, R. J., Boccippio, D. J., et al.: Global frequency and distribution of lightning as observed from space by the Optical Transient Detector, J. Geophys. Res., 108(D1), 4005, doi:10.1029/2002JD002347, 2003.

Crassier, V., Suhre, K., Tulet, P., and Rosset, R.: Developement of a reduced chemical scheme for use in mesoscale meteorological models, Atmos. Environ., 34, 2633-2644, 2000.

Danielsen, E. F.: In situ evidence of rapid, vertical, irreversible transport of lower tropospheric air into the lower stratosphere by convective cloud turrets and by large scale up welling in tropical cyclones, J. Geophys. Res., 98, 8665-8681, 1993.

Deeter, M. N., Emmons, L. K., Edwards, D. P., Gille, J. C., and Drummond, J. R.: Vertical resolution and information content of CO profiles retrieved by MOPITT, Geophys. Res. Lett., 31, L15112, doi:10.1029/2004GL020235, 2004.

Dentener, F., Stevenson, D., Cofala, J., Mechler, R., Amann, M., Bergamaschi, P., Raes, F., and Derwent, R.: The impact of air pollutant and methane emission controls on tropospheric ozone and radiative forcing: CTM calculations for the period 19902030, Atmos. Chem. Phys., 5, 1731-1755, 2005, http://www.atmos-chem-phys.net/5/1731/2005/.

Dessler, A. E.: The effect of deep, tropical convection on the tropical tropopause layer, J. Geophys. Res., 107, 4033, doi:10.1029/2001JD000511, 2002.

Drummond, J. R. and Mand, G. S.: The Measurements of Pollution in the Troposphere (MOPITT) instrument: Overall performance and calibration requirements, J. Atmos. Oceanic Technol., 13, 314-320, 1996.

Emmons, L. K., Deeter, M. N., Gille, J. C., et al.: Validation of Measurements of Pollution in the Troposphere (MOPITT) CO retrievals with aircraft in situ profiles, J. Geophys. Res., 109, D03309, doi:10.1029/2003JD004101, 2004. 
Emmons, L. K., Pfister, G. G., Edwards, D. P., Gille, J. C., Sachse, G., Blake, D., Wofsy, S., Gerbig, C., Matross, D., and Nédélec, P.: Measurements of Pollution in the Troposphere (MOPITT) validation exercises during summer 2004 field campaigns over North America, J. Geophys. Res., 112, D12S02, doi:10.1029/2006JD007833, 2007.

Filipiak, M. J., Harwood, R. S., Jiang, J. H., Li, Q., Livesey, N. J., Manney, G. L., Read, W. G., Schwartz, M. J., Waters, J. W., and Wu, D. L.: Carbon monoxide measured by the EOS Microwave Limb Sounder on Aura: First results, Geophys. Res. Lett., 32, L14825, doi:10.1029/2005GL022765, 2005.

Folkins, I., Bernath, P., Boone, C., Lesins, G., Livesey, N., Thompson, A. M., Walker, K., and Witte, J. C.: Seasonal cycles of $\mathrm{O}_{3}$, $\mathrm{CO}$, and convective outflow at the tropical tropopause, Geophys. Res. Lett., 33, L16802, doi:10.1029/2006GL026602, 2006.

Frankenberg, C., Meirink, J. F., Bergamaschi, P., Goede, A. P. H., Heimann, M., Körner, S., Platt, U., van Weele, M., and Wagner, T.: Satellite chartography of atmospheric methane from SCIAMACHY on board ENVISAT: Analysis of the years 2003 and 2004, J. Geophys. Res., 111, D07303, doi:10.1029/2005JD006235, 2006.

Frisk, U., Hagström, M., Ala-Laurinaho, J., et al.: The Odin satellite I: Radiometer design and test, Astron. Astrophys., 402(3), L27L34, doi:10.1051/0004-6361:20030335, 2003.

Froidevaux, L., Liversey, N. J., Read, W. G., et al.: Early validation analyses of atmospheric profiles from EOS MLS on the Aura satellite, IEEE Trans. Geosci. Remote Sensing, 44(5), 11061121, 2006.

Fueglistaler, S., Wernli, H., and Peter, T.: Tropical troposphereto-stratosphere transport inferred from trajectory calculations, J. Geophys. Res., 109, D03108, doi:10.1029/2003JD004069, 2004.

Gettelman, A., Randel, W. J., Wu, F., and Massie, S. T.: Transport of water vapour in the tropical tropopause layer, Geophys. Res. Lett., 29, 1009, doi:10.1029/2001GL13818, 2002.

Giglio, G., Kendall, J. D., and Tucker, C. J.: Remote sensing of fires with the TRMM VIRS, Int. J. Remote Sens., 21, 203-207, 2000.

Grosvenor, D. P., Choularton, T. W., Coe, H., and Held, G.: A study of the effect of overshooting deep convection on the water content of the TTL and lower stratosphere from Cloud Resolving Model simulations, Atmos. Chem. Phys., 7, 4977-5002, 2007, http://www.atmos-chem-phys.net/7/4977/2007/.

Heald, C. L., Jacob, D. J., Palmer, P. I., Evans, M. J., Sachse, G. W., Singh, H. B., and Blake, D. R.: Biomass burning emission inventory with daily resolution: Application to aircraft observations of Asian outflow, J. Geophys. Res., 108(D21), 8811, doi:10.1029/2002JD003082, 2003.

Holton, J. R., Haynes, P. H., Douglass, A. R., Rood, R. B., and Pfister, L.: Stratosphere-troposphere exchange, Rev. Geophys., 33, 403-439, 1995.

Josse, B., Simon, P., and Peuch, V.-H.: Rn-222 global simulations with the multiscale CTM MOCAGE, Tellus, 56B, 339-356, 2004.

Lefèvre, F., Brasseur, G. P., Folkins, I., Smith, A. K., and Simon, P.: Chemistry of the 1991-1992 stratospheric winter: Threedimensional model simulations, J. Geophys. Res., 99, 91838195, 1994.

Levine, J. G., Braesicke, P., Harris, N. R. P., Savage, N. H., and Pyle, J. A.: Pathways and timescales for troposphere-tostratosphere transport via the tropical tropopause layer and their relevance for very short lived substances, J. Geophys. Res., 112, D04308, doi:10.1029/2005JD006940, 2007.

Li., Q., Jiang, J. H., Wu, D. L., et al., Convective outflow of South Asia pollution: A global CTM simulation compared with EOS MLS observations, Geophys. Res. Lett., 32, L14826, doi:10.1029/2005GL022762, 2005.

Liebmann, B. and Smith, C. A.: Description of a Complete (Interpolated) Outgoing Longwave Radiation Dataset, B. Am. Meteorol. Soc., 77, 1275-1277, 1996.

Livesey, N. J., Read, W. G., Filipiak, M. J., et al.: Earth Observing System (EOS) Microwave Limb Sounder (MLS), Version 1.5 Level 2 data quality and description document, Jet Propulsion Laboratory, Tech. Rep., D-32381, available on the MLS websiteL http://mls.jpl.nasa.gov, 2005.

Livesey, N. J., Van Snyder, W., Read, W. G., and Wagner, P. A.: Retrieval algorithms for the EOS Microwave Limb Sounder (MLS) instrument, IEEE Trans. Geosci. Remote Sensing, 44(5), 1144$1155,2006$.

Liu, C. and Zipser, E. J.: Global distribution of convection penetrating the tropical tropopause, J. Geophys. Res., 110, D23104, doi:10.1029/2005JD006063, 2005.

Michou, M. and Peuch, V.-H.: Surface exchanges in the MOCAGE multiscale Chemistry and Transport Model, J. Water Sci., 15, 173-203, 2002.

Michou, M., Laville, P., Serça, D., et al.: Measured and modeled dry deposition velocities over the ESCOMPTE area, Atmos. Res., 74, 89-116, doi:10;1016/j.atmosres.2004.04.011, 2004.

Murtagh, D., Frisk, U., Merino, F., et al.: An overview of the Odin atmospheric mission, Can. J. Phys., 80, 309-319, 2002.

Newell, R. W. and Gould-Stewart, S.: A Stratospheric Fountain?, J. Atmos. Sci., 38, 2789-2796, 1981.

Park III, J. H., Gordley, L. L., Drayson, S. R., Benner, D. C., McInerney, J. M., Gunson, M. R., Toon, G. C., Sen, B., Blavier, J.-F., Webster, C. R., Zipf, E. C., Erdman, P., Schmidt, U., and Schiller, C.: Validation of Halogen Occultation Experiment $\mathrm{CH}_{4}$ measurements from the UARS, J. Geophys. Res., 101(D6), $10183-$ 10 204, 10.1029/95JD02736, 1996.

Park, M., Randel, W. J., Kinnison, D. E., Garcia, R. R., and Choi, W.: Seasonal variation of methane, water vapor, and nitrogen oxides near the tropopause: Satellite observations and model simulations, J. Geophys. Res., 109, D03302, doi:10.1029/2003JD003706, 2004.

Pommereau, J.-P., Garnier, A., Held, G., Gomes, A.-M., Goutail, F., Durry, G., Borchi, F., Hauchecorne, A., Montoux, N., Cocquerez, P., Letrenne, G., Vial, F., Hertzog, A., Legras, B., Pisso, I., Pyle, J. A., Harris, N. R. P., Jones, R. L., Robinson, A., Hansford, G., Eden, L., Gardiner, T., Swann, N., Knudsen, B., Larsen, N., Nielsen, J., Christensen, T., Cairo, F., Pirre, M., Marécal, V., Huret, N., Riviére, E., Coe, H., Grosvenor, D., Edvarsen, K., Di Donfrancesco, G., Ricaud, P., Berthelier, J.-J., Godefroy, M., Seran, E., Longo, K., and Freitas, S.: An overview of the HIBISCUS campaign, Atmos. Chem. Phys. Discuss., 7, 2389-2475, 2007, http://www.atmos-chem-phys-discuss.net/7/2389/2007/.

Pommereau, J.-P. and Held, G.: Is there a stratospheric fountain?, Atmos. Chem. Phys. Discuss., 7, 8933-8950, 2007, http://www.atmos-chem-phys-discuss.net/7/8933/2007/.

Rasch, P. J., Mahowald, N. M., and Eaton, B. E.: Representations of transport, convection, and the hydrologic cycle in chemical 
transport models: Implications for the modeling of short-lived and soluble species, J. Geophys. Res., 102(D23), 28 127-28 138, 10.1029/97JD02087, 1997.

Richard, E. C., Tuck, A. F., Aikin, K. C., Kelly, K. K., Herman, R. L., Troy, R. F., Hovde, S. J., Rosenlof, K. H., Thompson, T. L., and Ray, E. A.: High-resolution airborne profiles of $\mathrm{CH}_{4}$, $\mathrm{O}_{3}$, and water vapor near tropical Central America in late January to early February 2004, J. Geophys. Res., 111, D13304, doi:10.1029/2005JD006513, 2006.

Rodgers, C. D.: Inverse methods for atmospheric sounding: theory and practice, 1st ed., World Sci., River Edge, N. J., 2000.

Russell III, J. M., Gordley, L. L., Park, J. H., et al.: The Halogen Occultation Experiment, J. Geophys. Res., 98, 10777-10797, 1993.

Schoeberl, M. R., Duncan, B. N., Douglass, A. R., Waters, J., Livesey, N., Read, W., and Filipiak, M.: The carbon monoxide tape recorder, Geophys. Res. Lett., 33, L12811, doi:10.1029/2006GL026178, 2006.

Sherwood, S. C. and Dessler, A. E.: On the control of stratospheric humidity, Geophys. Res. Lett., 27(16), 2513-2516, doi:10.1029/2000GL011438, 2000.

Sherwood, S. C., Chae, J.-H., Minnis, P., and McGill, M.: Underestimation of deep convective cloud tops by thermal imagery, Geophys. Res. Lett., 31, L11102, doi:10.1029/2004GL019699, 2004.

Teyssèdre, H., Michou, M., Clark, H. L., Josse, B., Karcher, F., Olivié, D., Peuch, V.-H., Saint-Martin, D., Cariolle, D., Attié, J.-L., Ricaud, P., Van der A, R. J., and Chéroux, F.: A new chemistry-climate tropospheric and stratospheric model MOCAGE-Climat: evaluation of the present-day climatology and sensitivity to surface processes, Atmos. Chem. Phys. Discuss., 7, 11 295-11398, 2007.
Tiedtke, M.: A comprehensive mass flux scheme for cumulus parametrization in large scale models, Mon. Wea. Rev., 117, 1779-1800, 1989.

Urban, J., Lautié, N., Le Flochmoën, E., et al.: Odin/SMR limb observations of stratospheric trace gases: Level 2 processing of $\mathrm{ClO}, \mathrm{N}_{2} \mathrm{O}, \mathrm{HNO}_{3}$, and $\mathrm{O}_{3}$, J. Geophys. Res., 110, D14307, doi:10.1029/2004JD005741, 2005.

van der Werf, G. R., Randerson, J. T., Collatz, G. J., and Giglio, L.: Carbon emissions from fires in tropical and subtropical ecosystems, Global Change Biol., 9, 547-562, 2003.

Waters, J. W., Froidevaux, L., Harwood, R. S., et al.: The Earth Observing System Microwave Limb Sounder (EOS MLS) on the Aura satellite, IEEE Trans. Geosci. Remote Sensing, 44(5), 1075-1092, 2006.

Waugh, D. W. and Hall, T.: Age of stratospheric air: theory, observatiosn and models, Rev. Geophys., 40(4), 1010, doi:101029/2000RG000101, 2002.

World Meteorological Organization, Scientific assessment of ozone depletion: 1998, Rep. 44, Geneva, Switzerland, 1998. 